\title{
DEMOCRACY IN AUTHORITARIAN STATES? POLITICAL CHANGE AND REGIME STABILITY IN MALAYSIA AND SINGAPORE.
}

\section{By}

Aaron Anandarajah S. Kunaraja

\author{
A thesis \\ submitted to the Victoria University of Wellington \\ in fulfilment of the requirements for the degree of \\ Master of Arts \\ in Political Science
}

Victoria University of Wellington

2014 


\section{Table of Contents}

$\begin{array}{ll}\text { Abstract } & \text { p.2 }\end{array}$

$\begin{array}{lc}\text { Acknowledgements } & \text { p.3 }\end{array}$

$\begin{array}{lr}\text { Introduction } & \text { p.4 }\end{array}$

Chapter 1: History of competitive authoritarianism in Malaysia and Singapore $\quad$ p.20

Chapter 2: Factors promoting regime stability in Malaysia and Singapore p.49

$\begin{array}{ll}\text { Chapter 3: Recent developments and prospects for change } & \text { p.67 }\end{array}$

$\begin{array}{lr}\text { Conclusion } & \text { p.95 }\end{array}$

$\begin{array}{lr}\text { Bibliography } & \text { p.97 }\end{array}$ 


\section{Abstract}

In Political Science literature, Malaysia and Singapore have consistently been classified as semi-democracies; combining elements of democracy such as regularly-held elections with restrictions on civil liberties more reminiscent of authoritarian regimes. Semi-democracy or competitive authoritarianism in both countries have been relatively stable with extended periods of strong economic performance. However, recent developments in the country's political scene have cast some doubt on the resilience of such a system.

In the case of Malaysia, the last two elections have shown a consistent loss in support for the ruling Barisan Nasional or National Front coalition which has been in power since independence in 1957. It also appears that restrictions on civil liberties have been lifted, albeit partially. The 'complacency' that existed among the middle class previously has largely given way while civil society is playing a much more prominent role in public discourse.

Singapore has also experienced similar developments, though not to the extent to the extent of the 'political tsunami' in Malaysia. Nevertheless the ruling PAP had its lowest share of the popular vote in decades in the 2011 elections and Singaporean society is increasingly vocal about grievances regarding income inequality.

Keeping in mind that there has been little structural change to the electoral system that still heavily favours the incumbent government and that key institutions of the state are still controlled by the ruling party, are both countries in a transition process to a more democratic system or will the ruling coalition retain power through these structural and institutional arrangements for the foreseeable future? In other words, will two of the world's longest-running competitive authoritarian or semi-democratic states be resilient enough to withstand the pressures for change? 


\section{Acknowledgements}

First and foremost, I would like to thank God for giving me the perseverance and dedication that helped see me through the completion of this thesis.

I would like to begin by thanking my supervisor, Associate Professor Ben Thirkell-White for his invaluable assistance throughout the production of this thesis. Without his guidance, I would not have been able to complete this piece of work. I would also like to thank Dr. Joe Burton and Dr. Manjeet Pardesi who were more than willing to offer their thoughts and advice to me during my tenure as an MA student in the department. Besides them, I would also like to take this opportunity to thank Philippa Race, the postgraduate administrator whose office door was always open when I needed to resolve any issues related to my candidature.

To my parents, and dear friends, I would like to express my heartfelt gratitude. Thank you mom and dad, for providing moral support and helping me keep focus, especially during those trying times in the lead up to submission. Thank you Reneeta, Bryan, Muhammad and Paee, for being there when I needed the encouragement and support. I could not have done it without you guys.

To my postgraduate colleagues, Alex, Andrew, David and Rebekah, thank you for providing that sense of community in an otherwise solitary life of a postgraduate thesis student. I appreciate the feedback and encouragement I received from each and every one of you. 


\section{Introduction}

Since the third wave of democratisation, many of the states that underwent political change have gradually consolidated democratic politics with strong elements of authoritarian rule into a hybrid regime of sorts. The spectrum of regime types within these group of hybrid regimes itself are very diverse, ranging from those that are nearly liberal democracies in the Western sense to those that are almost open dictatorships. In the case of Singapore and Malaysia, both these two states can be categorized as hybrid regimes. More specifically and for the purposes of this research, they can be further classified as competitive authoritarian states. To put it succinctly, competitive authoritarian states are characterized by single party dominant systems where regular multiparty elections are held but where opposition parties have an extremely limited chance of winning these elections due to a system that limits their competitiveness in favour of the dominant party (Case, 2010; 2005; 1996).

Malaysia and Singapore are prime examples of this. While regular elections are held that are purported to be free and fair, there has been no change of government in both countries since they first started having elections. The formal and informal institutions enacted by the ruling parties of both states to regulate freedom of speech and assembly and in turn limit the possibility of a viable opposition from developing. The ruling parties in both states have become so entrenched in the political architecture and governance of their respective countries that the distinction between party and government is blurred (Maclntyre, 2003; Case, 2005).

The current literature available on competitive authoritarianism indicate that these states are more durable and stable compared to full-fledged democracies as well as authoritarian states in developing countries (Levitsky \& Way, 2010). The case of Malaysia and Singapore until recently has largely confirmed this. For the large part of their existence since gaining independence, both countries experienced political stability and peace, although Malaysia had some problems with communist insurgencies during the 1950s and 1960s as well as a racial riot in 1969 which spilled over to Singapore. Even then, these incidents pale in comparison to the level of violence and political instability witnessed in many of their Southeast Asian neighbours such as Indonesia, Thailand, Burma and the Philippines. With 
Singapore graduating to a developed country status and Malaysia not far behind, the new economic clout enjoyed by their respective citizens and the rise of the middle class has posed a challenge for the legitimacy of single party dominant systems in both countries.

Recent political developments in both Singapore and Malaysia calls into question the durability of these regime types amidst increasing demands for political liberalization by its citizens. Despite predictably winning them, the most recent elections in both countries have been the worst performances for the UMNO led coalition in Malaysia and the PAP in Singapore since their formation. Ever since that poor showing, the ruling party in both states had to make accommodations in order to satisfy a more politically vocal citizenry. This included lifting restrictions on freedom of speech and in the case of Malaysia, promising greater transparency and accountability, eroding elements of the competitive authoritarian system.

At this stage, it is unclear whether competitive authoritarianism will continue to be a viable political system for the ruling parties in both states. This is especially true in the case of Malaysia, where for the first time the opposition coalition is seen to have an outside chance of winning the upcoming elections which is to be held before May 2013. In Singapore, public support for the PAP is at an all-time low, with the Worker's Party now emerging as a rallying point for a previously fragmented opposition. Nevertheless, the ability of competitive autocracies to adapt to the political climate by accommodating greater democratic demands while maintaining its grip on power is precisely why it has proven to be such a stable model of government in the developing world. Given the high levels of economic progress achieved coupled with a population that have become more politically aware, this paper will investigate the durability of the single party dominant system in Malaysia and Singapore in the face of both internal and external pressures for political democratization.

\section{Research Question}

Will the institutional strength of the single-party dominant political systems in Malaysia and Singapore prevent these two states from transitioning into 'fuller' forms of democracy in light of growing pressures for democratization? 


\section{Elaboration}

Current thinking in democratic transition theory literature maintain that single party dominant systems or authoritarian systems in general will begin their transition to more democratic regimes during times of economic crisis, through the party's loss of patronage and elite-level defections. The multiparty elections that follow this subsequently add to the decline of party power and the democratization of politics (Case, 2010). This view can help explain Indonesia's transition from an authoritarian regime under Suharto to a democracy after the 1998 economic crisis that badly affected the region.

However, this did not occur in Singapore and Malaysia. In the case of Singapore, the PAP (People's Action Party) leadership managed to successfully weather the crisis, thus removing the necessary pre-condition of an economic crisis to occur before democratic change can happen. In Malaysia on the other hand, it seemed initially that political change was occurring. Disagreements on how to handle the economic crisis caused the Deputy Prime Minister Anwar Ibrahim to fall out of favour with Prime Minister Mahathir Mohamad. The former was eventually arrested and thrown into prison, resulting in nationwide protests supporting the former deputy. However, Mahathir's strong grip on UMNO and the country's key institutions such as the police and the judiciary helped the party to weather the political storm despite a strong opposition showing in the 1999 elections, and conditions quickly reverted to the status quo (Maclntyre, 2003, p. 79-84).

The strong grip over key institutions of the state by the ruling parties in both states has been attributed as one of the key reasons why democratic change did not happen in Malaysia and Singapore. While other Southeast Asian countries in the region such as Indonesia and Thailand were initially more authoritarian in nature, they were not considered strong states. Widespread corruption and elite-level patronage systems coupled with secessionist movements in both countries weakened the effectiveness state apparatus to the point where during the time of the economic crisis they were unable provide the public goods and services necessary to an increasingly disenchanted public (Slater, 2012 ; Ortmann, 2011). 
Singapore and Malaysia in contrast are strong states. The state apparatus has consistently managed to meet the expectations of the general public by providing the basic public goods and services needed. While Singapore arguably does this better than Malaysia, both states are far ahead compared to the rest of Southeast Asia in this area, with the exception of Brunei. Dan Slater points out that the extraordinary strength of the state apparatus in both countries has allowed a stable environment for competitive authoritarianism to flourish (2012). State strength is a key component of the single party dominant system in Malaysia and Singapore. It is precisely this reason which allowed UMNO and the PAP to maintain its grip on power for so long while authoritarian regimes in Indonesia, the Philippines and Thailand crumbled. However, recent developments in have called into question the durability of competitive authoritarianism in both countries.

Despite a strong state apparatus that works against it, the opposition parties in Malaysia and to a lesser extent Singapore had the strongest showings ever posted in each country's most recent elections, in 2013 and 2011 respectively. The People's Pact opposition coalition managed to win an unprecedented number of seats and for the second time (the first being in the 2008 elections) denied the UMNO-led National Front its customary two-thirds majority in parliament. While less dramatic than the situation in Malaysia, the PAP secured its lowest ever popular vote since independence in Singapore's most recent elections in 2011. Even though the PAP still won the lion's share of seats in parliament, the Workers Party managed to rise above the fragmented opposition to become by winning all the seats that did not go to the PAP (Barr, 2012). The recent January 2013 by-election came as a further setback to the PAP as it lost its seat in Punggol East to the Workers Party, cementing the latter's position as the main opposition party (O'Callaghan, 2013).

What is interesting about these developments is that it potentially challenges the long-held view that democratic transitions will most likely take place during periods of crises. Some scholars such as William Case have taken a new approach in trying to analyse the current situation in Malaysia and Singapore. He argues that voters in competitive authoritarian states like Malaysia now approach elections in new ways, using the limited competitiveness that had once helped to maintain the dominant party's legitimacy to cast ballots in concerted protests based on a wide variety of grievances they have against the ruling party 
(2010). This means that change no longer necessarily originates in the failure of the dominant party to generate patronage and manage elite relations, which UMNO and the PAP manage to do exceedingly well. Rather, political change can take place when the dominant party fails to meet the expectations of voters that they assess as being legitimate or at least worthy of support (Case, 2010).

While electoral manipulation is one method in which single party dominant states maintain their hold on power, they add to the grievances of citizens and the lingering competitiveness that remains offer voters a mechanism in which political change may occur. This was clearly the case in Malaysia. Even with alleged cases of electoral manipulation, the grievances associated with elite-patronage politics at the expense of the general population resulted in a concerted ballot-box protest against $t$ that culminated in the failure of UMNO and its National Front coalition to gain a two-thirds majority in parliament. While a transition to democracy has not been achieved in Malaysia, the electoral liberalization from the 2008 elections could signal a start to more concrete changes in the political system (Case, 2010). Since that watershed election UMNO have made several concessions to a citizenry that is more politically savvy than it ever was, by lifting some restrictions on freedom of speech and assembly and allowing more opportunities for civil society and opposition groups to voice out their views in the public sphere.

While the promise of democratic change in Malaysia seems like an outside possibility, Ortmann and Barr view this proposition to be a distant idea in the case of Singapore (Ortmann, 2011; Barr, 2012). In contrast to the Malaysian situation, the PAP leadership actively views the adversarial nature of democracy as inherent with risks and as such have taken it upon themselves to seek more non-adversarial and consensus-based approaches to air public opinion and complaints. The Nominated Member of Parliament or NMP whose nomination is by a vote of parliament, is part of this larger approach of actively fostering the non-adversarial alternatives to give a voice to public opinion and deter competitive politics (Jayasuriya \& Rodan, 2007b). 
Despite electoral setbacks, the legitimacy of the PAP is still stronger and the opposition presence is much smaller in parliament compared to their counterparts across the Causeway, partly due to the fact that they have managed to accommodate the grievances of citizens through concerted efforts like the NMP to include a more diverse range of views in the policy-making process. This institutional arrangement has arguably given more legitimacy to the PAP (Barr, 2012). The UMNO-led government, while more open to criticism than before, do not have a process in place such as the one created by the PAP government that allows them to accommodate alternative viewpoints into important policy decisions. Instead, by limited liberalisation of political space, without having mechanisms to draw in more public opinion when implementing major policy changes, they have unintentionally allowed the critical views of civil society groups and the opposition to echo to a much larger group of people than before. As such, it seems as if the prospects for democratic change are a higher possibility in Malaysia than it is in Singapore.

\section{Hypothesis}

The analysis of recent developments in both countries in relation to their single party dominant systems will provide a useful insight in the study of democratic transitions. A casestudy of these two countries can shed further light on when and how democratic transitions will take place in a competitive authoritarian system. It is hoped that this research project will add to the body of knowledge concerning the resilience of competitive authoritarian regimes in current conditions. While it is hard to reach a conclusive answer, as is the case with most questions in the social sciences, based on a detailed analysis this thesis will assert that the single party dominant system in Malaysia is more likely undergo a democratic transition in the near future as compared to Singapore due to the extent of the weakening perception of state capacity and legitimacy there.

\section{Structure}

The primary purpose of this research project is to examine the durability competitive authoritarian systems in Malaysia and Singapore in relation to growing pressures to democratize their respective political systems from the bottom-up. To do that, this paper will begin by looking at the relevant literature concerning democratisation in general and 
more specifically on the democratisation process in competitive authoritarian states or semi-democracies. The terms 'competitive authoritarianism' and 'semi-democracy' will be used interchangeably throughout this thesis, as both terms have been used to describe Malaysia and Singapore by various scholars. Following that, the paper will be divided into three parts. The first part will provide a concise historical narrative stretching from preindependence to decolonisation to the cold war era and will shed some insight into how the initially Westminster styled democracies evolved to become competitive authoritarian states incorporating elements of authoritarianism to democratic rule.

The second part will look at some of the key factors gathered from a review of the relevant literature that have allowed these regimes to remain remarkably stable throughout the 80s and 90s; amidst a sea of volatility across Southeast Asia that experienced revolutions, military coups and the Asian Financial Crisis. The single party-dominant systems that entrench authoritarian rule in both states will be studied and in particular the reasons why UMNO and the PAP have managed to hold on to power since the formation of both countries as independent nation states. The strong state factor will be looked at, in particular the success of the state in providing almost universal accessibility to public goods and services and realising economic progress that largely ensured successive electoral victories. The second key factor that will be studied is how these respective parties utilised their incumbent advantage through the skilful use and manipulation of state institutions and other resources at their disposal in restricting civil society and preventing the emergence of a politically viable opposition. In relations to this, the role of key institutions such as the judiciary, and the enforcement authorities in maintaining this dominant party rule will be highlighted. The third factor that this paper will cover is the role of strong leadership in consolidating authoritarian rule within a system that has competitive elections, focusing particularly on Mahathir Mohamad in Malaysia and Lee Kuan Yew in Singapore.

Following that, the third and final part will examine the recent political developments; principally developments relating to the 2008 and 2013 elections in Malaysia and the 2011 elections in Singapore and how this impacts upon the durability of the respective regimes. Of particular relevance would be the transformation of the previously politically passive 
middle class in both countries to a more engaged one. In relation to this, the emergence of civil society movements and the development of a credible opposition movement will also be highlighted. In the case of Malaysia and to a lesser extent Singapore, the relevance of race relations and ethnic-based politics will also be looked at in relation to the ability of the dominant party to maintain its hold on power. Ultimately this thesis will try to answer the question as to whether or not the institutional arrangements that exist in both countries will prevent the transition to a fuller form of democracy after examining all these factors.

This paper will be taking a comparative case-study approach to examine the research question, and will include a detailed study and comparison of the single party dominant systems in both counties. Due to time and resource constraints at this level of study, this project will rely primarily on current academic literature from books and journal articles as well as newspaper and online news reports on the political situation in both countries, due to the very current nature of the research topic.

\section{Literature on competitive authoritarian regimes}

Democratisation in competitive authoritarian states is an area within the greater body of research on democratization which has been difficult to explain. While there has been considerable work done on explaining transitions from non-democratic to democratic regimes, the democratization process in competitive authoritarian states, i.e. hybrid regimes that share the basic elements of electoral democracies combined with some authoritarian practices has been much harder to analyse and explain. This coupled with resilience of these semi-democracies, especially in the Asia-Pacific region has somewhat made this a grey area in most of the current literature, as previously well-supported conventional theories of democratization like modernization theory cannot be utilized to explain this. The challenge of this research therefore is to try and use existing literature that is available on the broader topic of democratization as well as more specific works on

democracy in Malaysia and Singapore; to construct a detailed explanation of the democratization process in that country. 
The conventional theories of democratisation focus mainly on the institutional structures and/or national actors in creating conditions for the emergence of democracy or in engineering the deals that make it possible. Modernization theory holds that economic development, a better educated citizenry and the development of a consumption culture as indicators for an emerging democratic order to emerge (Lipset, 1959; Giddens, 1990). Historical sociology emphasizes the centrality of the invisible structures of class for understanding any political order. The emergence of democracy correlates in particular with the development of an "articulate, self-conscious and organized working class or other subaltern movement" (Grugel, 2000: 239). Agency or transition theories meanwhile, reject the idea that democracy is an exceptional political order and viewed it as a possible outcome after authoritarian regimes breakdown, if elites and leaders are able to engage constructively, rationally and with a view to achieving compromise. Democracy becomes possible when institutions can be crafted in such a way as to guarantee the vital interests of elites. All these frameworks provide important and useful insights into the democratisation process, but do not by themselves explain sufficiently the case of competitive authoritarian states, or semi-democracies, transitioning to fuller democracies.

Besides domestic pressures, the international factor is increasingly seen as an important element in the democratization process, especially so with competitive authoritarian regimes. Levitsky and Way first introduce the concept of competitive authoritarianism as "civilian regimes in which formal democratic institutions exist, but they are not democratic because the playing field is heavily skewed in favour of incumbents" (2005: p. 35). They make the case that three independent factors determine whether a competitive authoritarian regime will become fully democratic or not. These three factors are: its linkage with the West, the leverage of the West on the regime and the regime's organizational capacity. Linkage to the West is defined as "the density of ties (economic, political, social, diplomatic and organizational) and cross-border flows (of capital, goods and services, people, and information). Of these three factors, they single out linkages to the West as the most crucial factor in the democratization process. They support this with evidence showing that regimes with high linkages to the West almost always democratized, regardless of context or background. Their argument is that Latin American regimes, states 
which have higher linkages to the West have democratized at a much greater rate than African and Asian regimes who do not have the same level of linkage to the West (Levitsky and Way, 2005).

The international factor however has had little influence in the democratization of East Asian regimes. The legacy of colonialism and external pressures had no direct influence in spurring democratic regime change in East Asia (Lee, 2002). As such, Levitsky and Way's emphasis on international linkages as a pressure factor for democratization cannot be applied to the case study countries as it has little relevance. Instead, the democratisation process in East Asia has and is exclusively based on domestic factors such as state capacity, the rise of the middle class and civil society. The lack of influence from external factors to democratize can be attributed to the prevailing culture of being highly protective of state sovereignty and non-interference in the internal matters of another state in the region. Due to colonial experience and the relatively young histories of most East Asian states as modern independent nation states, the principle of sovereignty is upheld to a much greater degree. The founding principles of ASEAN were based on sovereignty, territorial integrity and non-interference in the internal matters of another member state (Jones, 2011). With such a strong emphasis on sovereignty and non-interference, even in cases where neighbouring states have democratised, the external pressure to democratize was weak if not non-existent. The only exception to this was Cambodia, and even then it was mainly where international linkages to the West and Western leverage that were key drivers for its democratic transition (Haerpfer et.al, 2009).

In cases where there is a lack of linkage to the West, the other two variables come into play much more prominently. Western leverage in African states coupled with poor organisational capacity led many of those regimes to democratize, according to Levitsky and Way. In the case of Asian regimes, most had low to medium linkage to the West, mainly through economic ties, and high organisational capacities. This according to the authors has enabled some of the competitive authoritarian states in the Asia-Pacific region to resist pressures to democratize. Indeed, the strong organisational capacity of the state is seen as a strong deterrent for greater democratization by Levitsky and Way, in the absence of 
linkages and Western leverage. The case study country of Malaysia is regarded as a strong state. Based on Levitsky and Way's standards, both states have medium to high linkages to the West while also having high organizational capacities. With respect to the case study countries for this research, as mentioned earlier the international linkages with the West do not really play much of a role in regards to regime democratization. This leads to the question of how important state capacity is in enabling or discouraging democratization in competitive authoritarian regimes, or more specifically the two case study countries.

The strong grip over key institutions of the state by incumbent governments in successful competitive authoritarian regimes enable them to retain power while their counterparts are forced to democratise. The high state capacities of Malaysia and Singapore explains why these two countries have largely remained as semi-democratic regimes while other Southeast Asian countries in the region such as Indonesia and Thailand who were initially more authoritarian in nature went through a tumultuous period of transition during the Asian financial crisis as they were not considered strong states. Widespread corruption and elite-level patronage systems coupled with secessionist movements in Thailand and Indonesia weakened the effectiveness state apparatus to the point where during the time of the economic crisis they were unable provide the public goods and services necessary to an increasingly disenchanted public (Slater, 2012 ; Ortmann, 2011).

In this respect, the view that strong state capacity poses a stumbling block to the democratization process in not one shared by all comparativists and democracy theorists. Dan Slater argues that the strong institutional capacity of the state in Malaysia enables it to democratize much more smoothly as compared to states without strong capacities. Just as much as the organisational and institutional capacity of the state allows it to supress political pluralism, it is also seen as an important pre-condition in order for a successful democratization process to occur (2012). This view is shared by Jean Grugel, who attributes the development of a state that is able to "mediate conflict, set national goals, deliver public goods and extract the resources required to carry out these functions from society" (2000: p. 244) as an essential condition for a successful democratization process to occur. Slater pointed out that nations like Taiwan and South Korea are examples of regimes with strong 
states that managed to democratize much more peacefully than other states in the region which lack strong state capacity.

However, as pointed out earlier the resilience of competitive authoritarian or semidemocratic states is in part due to state capacity and adaptability. William Case in his many articles on the subject matter has stressed that the adaptability of competitive authoritarian states in Southeast Asia has allowed regimes to sustain, despite rapid economic development, a better educated and more globally connected citizenry and the emergence of a strong middle class. This has been largely due to the state's capacity to curb large middle class participation in mainstream politics by creating more incentives for economic growth and development while holding back on political reform (Case, 1993; 2002). In more recent times, the growing disaffection of the citizenry with the regime has so far been able to be neutralized albeit less effectively in times of elections through the 'menu of manipulation' aimed at enabling an electoral victory for the incumbent government. Case also attributes the skilfulness and adaptability of ruling governments in response to economic pressures artfully such as manipulating institutions in new ways, while mitigating new social inequalities as measures that can tide over their regimes until the economy recovers and societal grievances abate (2005). Unskilful manipulation that ignore inequalities within society however can cause a tide of voters to shift over the electoral barrier to produce significant setbacks for the ruling government, and can eventually result in the overturning of hybrid regimes through the ballot box.

It is also important to note the differences in economic progress between authoritarian regimes in East Asia as opposed to other parts of the world that contributed to regime durability. Unlike the rest of the democratizing world, many East Asian states have managed to achieve astounding levels of economic growth and social modernization under authoritarian rule. This pattern of rising economic prosperity and expanding social modernization is in stark contrast to the one of economic stagnation and social decay in Central and Eastern Europe under communist rule and Latin America under successive military dictatorships (Haggard and Kaufman, 1995; Linz and Stepan, 1996). With increased prosperity under authoritarian rule, citizens of East Asian states had lesser incentives to 
abandon authoritarian rule in favour of democracy than their counterparts in other authoritarian regimes. Impressive economic performance gave legitimacy to regimes in the region and as such the 'Third Wave' of democratization did not affect East Asia to the extent of Latin America, Central and Eastern Europe and Sub-Saharan Africa. Under this condition of a strong state apparatus together with policies aimed at social and economic modernization, the hybrid regimes of East Asia managed to produce a stable political system that could withstand pressures to democratize longer than their counterparts in other regions. The rise of a new middle class through economic progress however would prove to be a force for democratization later on, as in the cases of South Korea, Taiwan and Thailand. Indonesia democratized due to economic mismanagement and the repercussions of the Asian Economic Crisis of ' 97 which caused widespread social unrest. Economic stagnation and the rise of the middle class as a major domestic actor are important drivers for democratic transition to take place. The resilience of a competitive authoritarian regime will be tested in times of economic crises, especially when the ability of the middle class to enjoy their new-found standard of living and the social mobility of peasants and the working class are threatened.

Current thinking in democratic transition theory literature maintain that single party dominant systems or authoritarian systems in general will begin their transition to more democratic regimes during times of economic crisis, through the party's loss of patronage and elite-level defections. The multiparty elections that follow this subsequently add to the decline of party power and the democratization of politics, as witnessed in post-Suharto Indonesia (Case, 2010). In this regard, the resilience of competitive authoritarian regimes seems to rest on a delicate balance of state capacity, adaptability and skilfulness in 'playing the game'. Based on the literature available on hybrid regimes, it can be argued that these regimes may not be as resilient as they are made out to be, as their continued existence depends on a few crucial factors. Even if one of these conditions are not met, these competitive authoritarian regimes can and will face a strong reaction from the public through election results. The most recent election results in both case study countries show that the share of the popular vote for the ruling parties is gradually being reduced. It is not unforeseeable therefore that at one point in the future, the incumbent party will be voted 
out. Political change can take place when the dominant party fails to meet the expectations of voters that they assess as being legitimate or at least worthy of support (Case, 2010).

Besides a strong state, the role of civil society and social capital are also deemed to be important for democratisation to occur successfully according to Grugel (2000: p.242). These are the conditions that are necessary in order for successful democratization to take place in a state: An active civil society, or at least strong and well-organized social organisations, that pre-dates the transition or, minimally, are established during the course of it; a complex civil society, made up of a range of different groups, that is able to engage in processes of sustained collective action based on assuring the extension of citizenship rights throughout society; a transformation of the state, so that it can claim to represent democratically, and to be accountable to, the entire national community through the extension of citizenship to all, or at least most, adults who live within its boundaries; and a state that is able to mediate conflict, set national goals, deliver public goods and extract the resources required to carry out these functions from society (Grugel, 2000 : p. 243-244). High levels of social capital and a strong civil society are important prerequisites that enable democratic and economic consolidation (Haerpfer et.al, 2009: p. 161).

The emergence and development of a vibrant and complex civil society is seen by many as a strong precursor and enable for a state to democratize. While the role of civil society is still subdued in most competitive authoritarian states, their emergence has led to greater pressures being placed on the state to reform. As mentioned by Case, change in hybrid regimes in Southeast Asia oftentimes will come through protests and mass mobilization of people as opposed to just votes through the ballot box. A strong civil society is key in order to be able to sustain people movements and protests and in turn pressure governments to address grievances caused by inequalities due to governance. Civil society provides social capital that facilitates the development of democracy. Social capital builds on the notion of civic associationalism as a key element in shaping democratic attitudes. In East Asia, the growth of civil society organizations altered the balance of power between authoritarian rulers and democratic opposition forces. Indeed the expansion of social capital through civil society is generally considered to be the primary driver of democratization in East Asia, 
assisted by the rise of the middle class and shifting cultural perceptions on democratic rule (Alagappa, 2001; Quadir and Lele, 2005). Religious institutions in South Korea and a multitude of social movements in Taiwan and Thailand were prominent actors which promoted civil liberties and directly challenged autocratic regimes by demanding greater political reform. This ultimately led to democratic transitions in those countries (Haerpfer etl al., 2009). In the case study countries, there is a strong correlation between the increased vibrancy and presence of civil society movements and the declining popularity of the dominant parties, reflected in the percentage of the popular vote.

What this thesis seeks to achieve is to conduct a more specific analyses of the competitive authoritarian systems in both Malaysia and Singapore and the viability of these systems in light of societal pressures to democratise. While there is enough literature available to explain the democratisation process in general and how hybrid regimes democratise more specifically, there is a lack of literature that explains democratisation in Malaysia and Singapore. The case-specific literature available has not been able to keep up with the recent developments in the political situation in the country. It is hoped that by drawing on the broader work on democratisation and past works on hybrid regimes in Malaysia and Singapore, a more current analysis can be made.

The current literature concerning democratisation and more specifically democratisation in competitive authoritarian regimes does however provide a useful background in which to frame this research in. State capacity and adaptability in response to societal pressures is a key element which has enabled many hybrid regimes to remain in power. Continued economic progress allows the regime to maintain its legitimacy among ordinary citizens. On the other hand, the rise of the middle class through greater economic progress creates the potential of future challenges to the system. This coupled with higher levels of social capital and a more prominent civil society are a powerful force for democratisation in such regimes. At the same time, the existence of a strong state structure enables countries to democratise more peacefully and successfully compared to states which do not have such a structure in place. In this respect, the state strength vs. emerging social capital dynamic, 
derived primarily from the works of Case, Slater and Grugel provide the most useful framework in which to analyse the democratisation process in Malaysia and Singapore. 


\section{Chapter 1: The history and development of competitive authoritarianism in Malaysia and Singapore}

The overarching theme of this thesis is the (un)resilience of the competitive authoritarian regime system. Empirically, this regime type has been surprisingly resilient despite its 'halfway house' characteristics (Case, 2002). In the case of Malaysia and Singapore, competitive authoritarianism or semi-democracy has been especially resilient. The resilience of competitive authoritarianism in Malaysia and Singapore can largely be attributed to three broad factors: a compliant middle class, a fragmented opposition and weak civil society, and a ruling coalition that is adaptive and effective in controlling and manipulating state institutions in order to maintain power. In relation to that, this section will essentially set out the historical development of strong states in Malaysia and Singapore and how historical incidences have contributed to state strength. The desire for order and stability during a period when many countries in the region were experiencing violent political conflict was an important driver for the establishment of a strong state apparatus in Malaysia and Singapore. To understand the complexities of the competitive authoritarian state in Malaysia and Singapore, one would also have to examine the prominence of race and ethnicity in the political environment. Being multi-ethnic and multi-religious nations in a time of political upheaval in neighbouring countries, having strong state capacity was seen as a vital element in preserving the stability and sovereignty in both countries. In relation to this, a succinct but comprehensive review of both nation histories from the colonial preindependence onwards will shed more light as to how these countries gradually evolved from an archetypal British- styled democracy into an authoritarian semi-democracy or competitive authoritarian state. 


\section{A: Malaysia}

\section{Background}

Malaya, as the nation was known initially, gained independence at the end of August, 1957. In September 1963, two British colonies in the island of Borneo: Sabah and Sarawak, and the self-governing British protectorate of Singapore (expelled in 1965) joined Malaya to form the Federation of Malaysia. While Malaya or peninsular Malaysia as it is now called only constituted about two thirds of the total land area, it housed 80 percent of the population (Milne \& Mauzy, 1999). Due to this, politics at the national level is dominated by peninsular politicians and peninsular-based parties, with ethnic considerations coming to the fore. Malaysia is characterized by its multi-ethnic and multi-religious society. In a

country with a population of over 28 million people, the Malay/Bumiputra make up approximately 61 percent of the population (CIA, 2012). It is important to note that Malays constitute the majority of the Bumiputra race, which consists of other smaller indigenous groups. Malays alone account for more than 50 percent of the total population of Malaysia; as such are they are the dominant ethnic group in the country (CIA, 2012; Cheah, 2004). The largest ethnic minority groups are the Chinese, who constitute 24 percent of the population. Indians are the second largest ethnic minority in Malaysia, form about 7 percent of the population with other non-Bumiputra groups and Eurasians forming the remaining 8 percent of the population. 
Figure 1.1

Carta 7: Taburan peratus penduduk mengikut kumpulan etnik, Malaysia, 2010

Chart 7: Percentoge distribution of the population by ethnic group, Malaysia, 2010

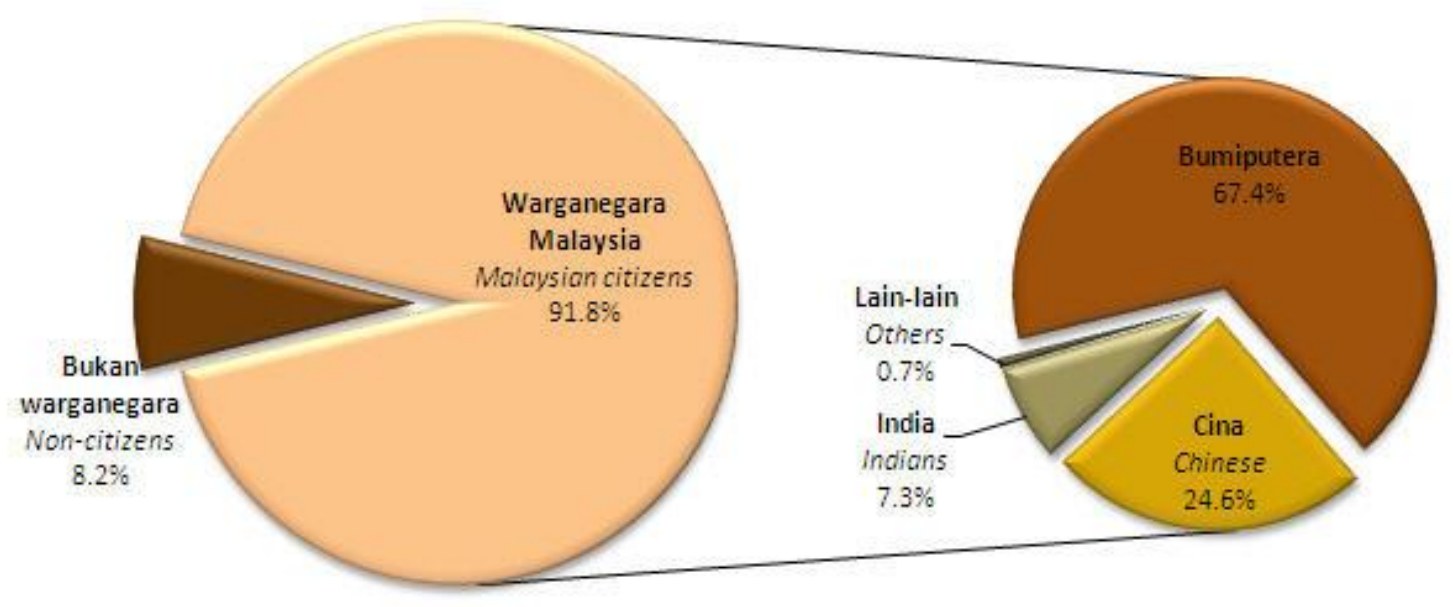

Source: Malaysian Statistics Department (2010)

In spite this diversity, the socio-political discourse throughout much of the country's history has largely been driven by ethno-religious concerns. This can be attributed to the policies of the colonial British government where the major ethnic groups were segregated based on geography and occupation. At the outset, all three major ethnic groups were segregated. They lived and worked separately, with little interaction between each group. The Malays were largely left to their own devices in the 'kampungs' or villages, where most of them were fisherman or subsistence farmers. The Chinese on the other hand were concentrated mainly in the urban areas which were close to the tin mines, and dominated small-time commerce and trade. Finally the Indians were largely based in the numerous rubber plantations and estates; the small minority who worked with the British administration were based in the administrative centres in the towns and thus had more interaction with other races such as the Chinese. As a result, genuine inter-ethnic interaction only existed among the middle classes in the urban areas where the population was more mixed. This 'divide and rule' policy was practiced by the British to reduce the risk 
of racial conflict from occurring as the Malays were becoming increasingly wary of the large number of immigrants in the country (Ariffin, 2009, p 47.). This approach also allowed the British to play the ethnic groups off each other while maintaining control over the country's administration and economy which was essentially designed to serve the needs of the Crown and the home economy of the United Kingdom (Abraham, 1997).

\section{Pre independence years}

As a result of this, all political issues gradually tended to coincide with and reinforced along ethnic, cultural and religious lines. Communal considerations were the order of the day and it continues to play an influential role to this very day (Crouch, 1996). Set against this backdrop, it is of no surprise then that Malayan politics in the years leading up to independence eventually came to be dominated by parties representing the various ethnic groups. However, while race was still an important factor, the overarching theme of preindependence politics following the post-war period was nationalism and anti-colonialism, rather than communalism per se. Various movements emerged during this period, and ranged from more moderate parties willing to work with the British establishment to more radical, left-leaning organisations that were openly anti-British. This anti-colonial sentiment reached its high point with the formation of the Malayan Union in April 1946, which streamlined the administration of British Malaya under one single system and provide a pathway to full independence. This system was heavily opposed by the Malay leaders and aristocrats, because it provided a relatively easy pathway for Chinese and Indian immigrants to obtain citizenship while reducing the power of the Malay Sultans with no guarantee of political primacy for the Malays. The non-Malays on the other hand were relatively silent, despite the terms of the Malayan Union agreement being arguably favourable for them.

Malays from both the conservative and progressive divide held nationwide protests against the Union. It was during this period that the United Malays National Organisation or UMNO was founded. It later went on to become the most dominant party in Malaysian politics. UMNO was the voice of the Malay aristocracy and elites and gained popular support among the Malay population, especially among the conservative sections of Malay society. As a

result of this widespread opposition, the British entered into secret negotiations with 
UMNO and the Malay rulers partly to prevent the hostility towards the Malayan Union from turning into anti-British sentiments that could empower the more anti-colonial and left wing organisations such as the Malayan Communist Party and the Malay Nationalist Party from gaining more popularity. The Malayan Union was discontinued and replaced with the Federation of Malaya Agreement in 1948, granting more favourable terms for the Malay Sultans and guaranteeing political supremacy for the Malay elites (Abraham, 1997). With this victory, UMNO secured its place as a leading player in Malayan politics.

Despite the prominence of UMNO during the early days, it was not without its challengers. Key among them was the Malay left-wing movement which mainly coalesced around another Malay nationalist party, the PKMM. The leaders of PKMM were seen as more radical than UMNO and was heavily influenced by the anti-colonial nationalist politics of Sukarno in neighbouring Indonesia. Leaders of PKMM were seen as more sympathetic to the working class and the Malay peasantry and as such drew their support base from there, much to the chagrin of the Malay aristocracy. Unlike UMNO though, their struggle was rooted on nationalism and independence, rather than solely safeguarding Malay interests. Together with the trade unions, the Malayan Communist Party and the more moderate Malayan Democratic Union, they formed a formidable front called the All-Malaya Council on Joint Action or AMCJA to oppose British policies. They organized a nationwide strike with the involvement of the trade unions, which was largely successful. Worried by the increasing popularity of their socialist leanings, the colonial government persuaded UMNO to broaden its appeal to the non-Malay population by recruiting other political parties. UMNO, which was also concerned about the threat posed by PKMM eventually entered into agreements with the Malayan Chinese Association (MCA), which was born out of the need to counter the influence of the Communist Party among the Chinese, and the Malayan Indian Congress (MIC). This political coalition became known as the Alliance.

With the presence of a political leadership that could represent the interests of all the major races that was British-friendly, the colonial authorities clamped down on AMCJA and the left-wing political movement. It is important to note that during this time period the colonial authorities were also actively involved in an armed campaign against a Communist insurgency in the country. A state of emergency was declared in 1948 to enable the colonial 
government to combat the guerrillas more effectively. Under the pretext of combating communism, key leaders from PKMM, MDU, and the trade unions were arrested and subsequently jailed, claiming they had links to the insurgency movement. The left-wing political movement crumbled after that, paving the way for the UMNO-led Alliance to be the primary political platform for independence and the dominant political movement. This can be clearly seen in the results of the very first general elections, held two years prior to the granting of full independence. The 1955 elections saw the Alliance coalition winning 51 of the 52 seats on offer. Thus, even before the formation of the Federation of Malaya, the ruling political coalition was already organized along racial lines.

\section{Independence to pre 1969 riots}

When Malaya gained independence in 1957, it had a constitution modelled on the Westminster form of government, following the British democratic system. Regular elections were supposed to be held, and universal suffrage for all citizens above the age of 21 was guaranteed. During the initial years following independence, politics were relatively open and the electoral process was largely devoid of criticism and allegations of irregularities. The nation's first Prime Minister, Tunku Abdul Rahman was a Cambridge educated UMNO Malay aristocrat who held fairly liberal views. However there were considerable limitations placed which curbed full political freedom. During the colonial post-war period a state of emergency was declared to counter Communist elements that were gaining ground. It was also used to suppress more nationalist and socialist political forces, paving the way for the colonial government-friendly Alliance to ultimately dominate the early nation's political space. This state of emergency lasted until 1960.

The provision for preventive detention was continued under the Internal Security Act or ISA, which gave the state far-ranging powers to arrest individuals without trial, and was mainly used against leftists, Communists, communalists and other opponents of the government (Crouch, 1996). Despite all this, the political situation in the country was relatively open from the moment of independence up until the aftermath of the 1969 general elections. The Malayan general election of 1959 and the Malaysian general elections of 1964 and 1969 were fairly competitive and were largely free from irregularities. 
In the 1959 elections, the Alliance won $52.1 \%$ of the popular vote and claimed 74 seats in a 104 seat parliament. The remaining 30 seats went to a range of opposition parties which included PAS and the now defunct Malayan People's Socialist Front. The 1964 elections saw the Alliance increase its popular mandate to $58 \%$ of the vote and winning 89 of the 104 seats. The elections were only held in the area which formerly constituted the Federation of Malaya, with Sabah and Sarawak scheduled to take part in the following election cycle while Singapore already held its own election days after the merger in September 1963. The tumultuous relationship between Malaya and Singapore and between the dominant UMNO party in the Alliance coalition and the ruling People's Action Party in Singapore due to ideological differences and the race factor (the Chinese community was politically dominant within the PAP and indeed Singapore) resulted in the first reported case of racial riots happening in the island state in 1964, where a large Malay gathering quickly escalated into a mob upon the agitation of ultra-nationalists from the Singapore branch of UMNO. There was a significant amount of damage to public property and 23 people were reported killed, with hundreds more injured.

The growing uneasiness between UMNO and the PAP was further exacerbated by this. Fearing that the challenge of integrating Chinese majority Singapore into the greater Malay polity would be too difficult a task, there was a strong sentiment within UMNO calling for Singapore's cessation from the Federation. Realising that it would be politically unfavourable to continue with the status quo, Tunku pressured his counterpart from the PAP, Lee Kuan Yew to secede from Malaysia. Due to the seemingly irreconcilable differences as well as pressure from the Tunku, Singapore was eventually expelled from the Federation in August 1965 and charted its own path towards nation-building. The events of 1964 were significant because it was the first time ethnic tensions spilled into violence and signaled that race relations were crucial in preserving stability in the nascent democracy. In light of this and based on the general sentiments of the Malay population, the UMNO led establishment began steps to advance Malay interests in the economy and consolidate Malay political dominance instead of just seeking to preserve and defend Malay interests. The '64 riots would also prove to be a precursor to much more widespread racial riots five years later in Malaysia. In spite of this however, the political climate in Malaysia continued 
to remain relatively free, dissent was still tolerated to a certain degree as long as it did not touch upon sensitive issues like race and religion. It was only after the events in 1969 that the political system Malaysia began to take a more authoritarian turn.

\section{General election and riots}

The 1969 general election was the most highly contested elections since independence and would remain as the closest fought until the 2008 and 2013 elections. While the Alliance managed to retain a parliamentary majority, it lost a significant number of seats there and sustained even heavier losses at the state level. The primarily rural Malay state of Terengganu and Kelantan fell to the Pan Malaysian Islamic Party which already had a significant support base in the rural north. The more urbanised and ethnically diverse state of Penang meanwhile was lost to the newly formed Gerakan party, which was contesting in its first elections. The Alliance were also dealt with heavy losses in Perak where the PPP put up a strong challenge, losing by only two seats. The DAP and Gerakan meanwhile made strong inroads in Selangor and the capital, Kuala Lumpur. The opposition managed to tie the Alliance in the Selangor state legislature, with the former only able to form the state government with the support of the sole independent member of the legislature. The DAP, PPP and Gerakan ran as a coalition and campaigned for a 'Malaysian Malaysia' i.e. the removal of special privileges for the Bumiputra community. They managed to attract considerable support from the non-Malay community, to the detriment of the Alliance's Chinese and Indian component parties. The Pan Malaysian Islamic Party meanwhile campaigned aggressively against UMNO and its perceived failure of not upholding the interest of the Malay poor. They managed to win a huge chunk of Malay votes especially in the rural heartland of the north who were convinced that the UMNO elite were not doing enough to meet their needs.

Table 1.1 Parliamentary Results of the 1969 Malaysian General Election

\begin{tabular}{|l|l|l||l||l|}
\hline \hline Party & Votes & $\%$ & Seats & $+/-$ \\
\hline \hline Alliance Party & $\mathbf{1 , 0 6 3 , 2 3 8}$ & $\mathbf{5 0 . 9}$ & $\mathbf{7 7}$ & -12 \\
\hline \hline United Malays National Organization (UMNO) & & & 51 & \\
\hline
\end{tabular}




\begin{tabular}{|c|c|c|c|c|}
\hline Malaysian Chinese Association (MCA) & & & 13 & \\
\hline Malaysian Indian Congress ( MIC) & & & 13 & \\
\hline Pan-Malaysian Islamic Party (PAS) & 495,641 & 20.9 & 12 & +3 \\
\hline Democratic Action Party (DAP) & 286,606 & 12.1 & 13 & +12 \\
\hline Parti Gerakan Rakyat Malaysia & 178,971 & 7.5 & 8 & New \\
\hline People's Progressive Party & 80,756 & 3.4 & 4 & +2 \\
\hline Sarawak United People's Party & 71,293 & 3.0 & 5 & New \\
\hline Sarawak National Party & 64,593 & 2.7 & 9 & New \\
\hline United Sabah National Organisation & 31,947 & 1.3 & 13 & New \\
\hline Parti Pesaka Sarawak & 30,765 & 1.3 & 2 & New \\
\hline Parti Rakyat & 25,785 & 1.1 & 0 & New \\
\hline United Malaysian Chinese Organisation & 1,808 & 0.1 & 0 & New \\
\hline Independents & 41,710 & 1.8 & 1 & +1 \\
\hline Invalid/blank votes & 134,230 & - & - & - \\
\hline Total & $2,532,042$ & 100 & 144 & +40 \\
\hline
\end{tabular}

Source: Nohlen et. al, 2001.

Soon after the results were announced, there was jubilation from the opposition front while the Alliance celebrations were much more subdued. In many ways, it was seen as a loss by most Alliance leaders as they did not expect to lose so many seats to the opposition. The opposition DAP and Gerakan parties, which drew their support mainly from the urban Chinese, organized victory rallies in Kuala Lumpur in celebration of their achievements. A procession was organized around the streets of the capital Kuala Lumpur in commemoration of their electoral victory on the $13^{\text {th }}$ of May, 1969. As per official accounts, the predominantly Chinese crowd antagonised Malay onlookers with racial epithets, as if to invite a response from them. The situation escalated when sections of the Malay crowd retaliated and acts of violence from both sides soon ensued (Kua, 2007). However, it is also true that the Selangor UMNO division under the helm of the state's Chief Minister and 
UMNO leader Harun Idris also mobilized large groups of Malay youth to counter the opposition procession with their own retaliatory parade. The two groups eventually met each other in the streets of the capital and tensions spilled over into open hostilities. Given that the DAP and Gerakan supporters on the streets were mainly Chinese and overwhelmingly non-Malay while the UMNO supporters were Malay, what was initially a political skirmish descended into racial riots, spreading across the capital and other major urban centres in the country with a large Chinese population. UMNO instigators initially fuelled the flames of conflict by capitalizing on the uneasiness among many Malays over Chinese economic dominance. With new-found political clout, it was feared that the opposition would soon begin to challenge the special privileges of the Bumiputra community, which the DAP along with Gerakan and PPP promised to review as part of their election manifesto (Kua, 2007).

\section{Aftermath of the Riots}

The riots dealt a significant blow to national unity. Official accounts state that 196 people were killed and hundreds more wounded. However, unofficial estimates put the numbers much higher. A few key developments emerged from this crisis that would see the country move closer towards authoritarian rule. The government immediately ordered a curfew in Kuala Lumpur and the state of Selangor. A state of emergency was declared throughout the whole country a day after the riots and order was quickly restored by the security forces. The curfew was eventually relaxed in other parts of the country within a few days of the incident while things returned to normal in Kuala Lumpur within a week. Some UMNO leaders led by the Deputy Prime Minister Tun Abdul Razak were critical of Tunku Abdul Rahman's leadership during these events. A week after that, a National Operations Council headed by Abdul Razak was formed with cabinet approval and its authority superseded that of the Parliament and the Prime Minister. With Parliament suspended, the NOC became the supreme law-making body in the country and its rule lasted for 18 months.

During this time, various security measures were introduced that curbed civil liberties. At the state level, the legislature and local government were also suspended and replaced by state and district level operations councils respectively. The NOC was composed of 
members of the Malay elite: bureaucratic, political and military as well as leaders from the MCA and MIC. Abdul Razak effectively became the most powerful man in the country and the Prime Minister, Tunku Abdul Rahman was gradually sidelined from the decision making process. Abdul Rahman's powers were considerably curtailed and he was eventually forced to resign from the premiership to make way for Abdul Razak in September 1970. The riots revealed pent-up frustrations among the Malays, who lagged behind the non-Bumiputra races economically (Crouch, 1996). The NOC and the UMNO elite concluded that the more moderate approach to racial issues typified by the policies of the Tunku would not be able to retain mass support among the Malays. . Besides losing the support of the non-Malays in the 1969 elections, what was more worrying for the UMNO leadership was the substantial loss in support among Malay voters to PAS, who championed the rights of the rural Malays. As such, under the leadership of Razak a new set of policies were launched in order to alleviate improve the economic and social standing of the Malays and Bumiputra.

At the same time, existing measures restricting freedom of speech were enforced while new measures were also introduced to limit political participation and curb the activities of the opposition parties. The line of thinking adopted by the country's political elite was that the riots showed how fragile race relations were in the country and that a liberal democratic political system would only exacerbate tensions between races instead of alleviating them. Controls were needed to ensure such an event will not happen again. Given the geopolitics of the time, and the spectre of Communism is looming strongly in Southeast Asia, stability and security were viewed as integral to the existence of the postcolonial state and sacrifices in personal liberties had to be made in order to preserve it. Among them were measures such as the Emergency Ordinance (EO) and the Internal Security Act (ISA). This was also a very persuasive pretext used in the aftermath of the riots to detain many of the political activists and leaders from the opposition parties who had leftwing leanings. These detainees were alleged to have had links with the Communist insurgency in Malaysia, which was still active at the time even though their influence had been greatly diminished by the time of the riots and were a spent force.

The Communist Party of Malaya served as a convenient scapegoat to blame for the events that took place on 13 May. Indeed the official version of events put out by the NOC point 
to the riots as a plot devised by the insurgents to destabilize the country in order to initiate a Communist revolution (Kua, 2007). Initially conceived and used as a tool to combat Communist activity during the 1960s, it would be used throughout the course of Malaysian politics by successive Prime Ministers to suppress dissent on the grounds of maintaining intercommunal harmony. Key targets were vocal civil and political activists but some politicians from the ruling party were also detained. Leaders from DAP, Gerakan and even PAS were detained under the ISA which provided for detention without trial for a period of up to 2 years. The DAP was the most heavily affected and its party apparatus was dealt a significant blow. The Gerakan, PAS and the PPP meanwhile were co-opted to join the Alliance coalition with promises of key appointments in the government. Gerakan was allowed to retain control of Penang and the state's Chief Minister's post. The way the ruling elite handled the aftermath of the riots marked a turning point in the country's political history as it moved closer towards an authoritarian system of government. The riots cemented the place of ethnicity in national politics and hastened the development of a strong and active role by the state in supressing dissent and maintaining control over the population. Ethnic fragmentation gave the ruling coalition the necessary justification in order to solidify its grip over government institutions.

\section{The New Economic Policy}

As part of a slew of new initiatives by the new Prime Minister to develop a stronger state and bring the Malay population up to speed with the country's development, the New Economic Policy was introduced in 1970. This policy at the outset had two seemingly altruistic goals, the eradication of poverty regardless of race and the restructuring of the national economy so as to eliminate identification of ethnicity with economic function (Goh, 1971). Affirmative action policies were put in place to favour more Malay/Bumiputra participation in the business sector while vigorously implementing Bumiputra quotas in the civil service and public tertiary institutes. As part of the NEP a Bumiputra equity target of $30 \%$ ownership of corporate resources was made. While the rationale behind this was that the economic development resulting from the implementation of the NEP would result in an enlargement of the pie so that non-Bumiputras can equally benefit, various other privileges were given to the Bumiputras that were perceived as side-lining non-Bumiputra 
economic participation. Preferential treatment in the awarding of business licenses, government tenders, scholarships and discounts on housing and special share ownership schemes reserved for Bumiputras meant that non-Malays increasingly felt they were being left out and discriminated against (Gomez, 2009). While the NEP managed to drastically reduce poverty levels in Malaysia and address the socio-economic imbalance between the Bumiputra and the Chinese to certain extent, it was heavily criticized for giving preferential treatment for Malay and Bumiputra communities at the expense of non-Bumiputras. Critics point to the NEP as the beginning of institutionalised marginalisation of nonMalay/Bumiputra ethnic groups (S.H. Ali, 2008).

Now, even though the non-Malays felt marginalised, the fact that the Malaysian economy experienced strong growth meant that in general everyone experienced a rise in the levels of personal income and well-being. At the same time, economic grievances of the Malay community were addressed quite effectively. Under the NEP, a policy of industrialisation and urbanisation was pursued. This led to the development of a strong manufacturing sector which provided many jobs for Malaysia's burgeoning population. The NEP therefore was quite successful in alleviating poverty and promoting economic development in the country. Thus the general sentiment among the Malays regarding the non-Malays and especially the Chinese became much less polarising. While grievances still existed between Malays and non-Malays and race relations were still problematic, it did not pose as much of challenge as it did before for the ruling elite. Stability and economic well-being proved to be strong factors that dissuaded people from voting against the Alliance, now renamed National Front coalition come election time. With sound economic policies that showed results i.e. an average annual growth rate of $8 \%$ throughout the 1970 s and a strong state apparatus that consistently managed to meet the expectations of the general public by providing basic public goods and services in key areas such as healthcare and education, the general population save for a few sections of the demographic largely voted in favour of the status quo. This would be reflected in the strong mandates won by the National Front in successive elections, where a two thirds majority in Parliament was consistently achieved. The NEP also played an important role in fostering the development of a strong state. Through the NEP, the state under the direct control of the ruling coalition becomes 
busily and effectively involved in promoting economic growth and progress. This became an important way in which UMNO and the National Front strengthened its legitimacy.

\section{Elections in the 1970 S}

The general elections held in the 1970s showed a convincing level of support for the competitive authoritarian regime of the National Front. In the 1974 general elections, just over 5 years after the events of 1969, the ruling coalition increased its seat share by 58 seats in Parliament while the DAP lost 9 seats. This led to the Sarawak National Party (SNAP), a largely regional party based in the East Malaysian state to become the largest opposition party in parliament. Overall the National Front managed to win 135 out of the 154 seats at the federal level, an overwhelming victory and a major improvement from its poor showing in 1969 (Nohlen et. al., 2001). The 1978 elections were no different. Abdul Razak died in 1976 due to ill health and was replaced by his deputy, Hussein Onn. Even though there was a new Prime Minister leading the National Front, the coalition managed to retain power easily. While there was an improved showing by DAP which gained 5 seats it lost during the last election and while the National Front lost a few more seats due to PAS leaving the coalition to become an opposition party again, the National Front managed to hold on to the bulk of its seats and won with a comfortable two-thirds majority in Parliament. Popular vote was also well above 50 percent. With such convincing victories, the National Front solidified its rule and the Malaysian political setup was effectively on course to become a single party dominant system.

Table 1.2 Parliamentary results of the 1974 General Elections

\begin{tabular}{|l|l|l|l|l|}
\hline Party & Votes & $\%$ & Seats & $+/-$ \\
\hline Barisan Nasional* & $\begin{array}{l}1,287,40 \\
0\end{array}$ & $\begin{array}{l}60 . \\
8\end{array}$ & 135 & +58 \\
\hline Democratic Action Party & 387,845 & $\begin{array}{l}18 . \\
\end{array}$ & 9 & -4 \\
\hline Sarawak National Party & 117,566 & 5.6 & 9 & 0 \\
\hline Social Justice Party & 105,718 & 5.0 & 1 & New \\
\hline
\end{tabular}




\begin{tabular}{|l|l|l|l|l|}
\hline Malaysian Socialist People's Party & 84,206 & 4.0 & 0 & New \\
\hline KITA & 8,623 & 0.4 & 0 & New \\
\hline $\begin{array}{l}\text { Independent People's Progressive } \\
\text { Party }\end{array}$ & 1,356 & 0.1 & 0 & New \\
\hline Independents & 124,202 & 5.9 & 0 & -1 \\
\hline Invalid/blank votes & 100,269 & - & - & - \\
\hline Total & $\mathbf{2 , 2 2 0 , 1 8}$ & $\mathbf{1 0 0}$ & $\mathbf{1 5 4}$ & $\mathbf{+ 1 4}$ \\
& $\mathbf{6}$ & & & \\
\hline
\end{tabular}

*PAS contested the 1974 election under the National Front/Barisan Nasional

Source: Nohlen et. al., 2001

Table 1.3 Parliamentary results of the 1978 GeneraL Elections

\begin{tabular}{|l|l|l|l|l|}
\hline Party & Votes & $\%$ & Seats & + /- \\
\hline Barisan Nasional & $\begin{array}{l}1,987,90 \\
7\end{array}$ & $\begin{array}{l}57 . \\
2\end{array}$ & 131 & -4 \\
\hline Democratic Action Party & 664,433 & $\begin{array}{l}19 . \\
1\end{array}$ & 16 & +5 \\
\hline PAS & 537,720 & $\begin{array}{l}15 . \\
\end{array}$ & 5 & New \\
\hline Sarawak People's Organisation & 10,151 & 0.3 & 1 & New \\
\hline Other parties & 112,850 & 3.2 & 0 & - \\
\hline Independents & 160,370 & 4.6 & 1 & +1 \\
\hline Invalid/blank votes & 123,302 & - & - & - \\
\hline Total & $\mathbf{2 , 2 2 0 , 1 8}$ & $\mathbf{1 0 0}$ & $\mathbf{1 5 4}$ & $\mathbf{+ 1 4}$ \\
& $\mathbf{6}$ & & & \\
\hline
\end{tabular}

Source: Nohlen et al., 2001

\section{Summary}

This section looked at the birth and the gradual development of a strong state in Malaysia. The formative years of the Malaysian state played a key role in the development of 
competitive authoritarianism. The history of the country from its pre-independence years up until the late 1970 s can essentially be surmised as that of a former British colony which initially had the trappings of a liberal democratic system that gradually became more authoritarian. The British crackdown on left-leaning nationalist political movements from the late 1940s to the early 1950s allowed the Malay elite-backed UMNO and its junior coalition partners the MCA and MIC to win the nation's first election in 1955 by a landslide and subsequent elections entrenched their position as the young nation's dominant political force. Despite this, restrictions placed on freedom of speech were fairly limited, even with the existence of politically repressive laws like the ISA, which was rarely if ever used to detain political opponents of the ruling elite up until the events of 1969. The 1969 general elections was the first serious electoral challenge that the National Front faced as it failed to gain a two thirds majority and parliament and lost a significant number of seats at the state level to various opposition parties. The race riots that followed marked the turning point of Malaysia's political direction and was a catalyst for the entrenchment of authoritarian practices in Malaysian democracy. The use of the ISA to detain opposition politicians and the establishment of the unelected NOC that overrode the authority of the Parliament for 18 months provided glimpses into how the executive, or more specifically the UMNO-led National Front would begin to later dominate key institutions of the state and the other branches of government, notably the judiciary. The political system in Malaysia took a sharp turn towards authoritarianism after the events of 1969 and embedded the rule of UMNO and the National Front for decades to come. Under strong economic development programmes initiated under the NEP, the state began to play a more activist role in promoting growth. The sustained levels of economic progress over the next two decades allowed the ruling coalition to keep up its efficient patronage machine while maintaining support among the voting population despite it limiting civil liberties. These combined with a muzzled opposition and civil society ensured the ruling coalition continued on its pattern of strong electoral showings and ensured the results of the 1969 general elections would not be repeated for the next few decades. 


\section{B: Singapore}

Table 1.4 Ethnic composition of Singapore's resident population

\begin{tabular}{|l|l|l|l|l|l|l|l|l|}
\hline Ethnic Group & $\mathbf{1 9 7 0}$ & $\mathbf{1 9 8 0}$ & $\mathbf{1 9 9 0}$ & $\mathbf{2 0 0 0}$ & $\mathbf{2 0 1 0}$ & $\mathbf{2 0 1 1}$ & $\mathbf{2 0 1 2}$ & $\mathbf{2 0 1 3}$ \\
\hline Chinese & $\mathbf{7 7 . 0 \%}$ & $\mathbf{7 8 . 3} \%$ & $\mathbf{7 7 . 8 \%}$ & $\mathbf{7 6 . 8 \%}$ & $\mathbf{7 4 . 1 \%}$ & $\mathbf{7 4 . 1 \%}$ & $\mathbf{7 4 . 2 \%}$ & $\mathbf{7 4 . 2 \%}$ \\
\hline Malays & $14.8 \%$ & $14.4 \%$ & $14.0 \%$ & $13.9 \%$ & $13.4 \%$ & $13.4 \%$ & $13.3 \%$ & $13.3 \%$ \\
\hline Indians & $7.0 \%$ & $6.3 \%$ & $7.1 \%$ & $7.9 \%$ & $9.2 \%$ & $9.2 \%$ & $9.2 \%$ & $9.1 \%$ \\
\hline Others & $1.2 \%$ & $1.0 \%$ & $1.1 \%$ & $1.4 \%$ & $3.3 \%$ & $3.3 \%$ & $3.3 \%$ & $3.3 \%$ \\
\hline
\end{tabular}

Source: Singapore Statistics Department, 2013.

Like Malaysia, Singapore has a multi-ethnic and multi religious population. Situated just a few miles across the Tebrau Straits from the southernmost Malaysian State of Johor, it is an island of only about 30 miles across, but houses a population of over 5 million. The city state has one of the highest population densities in the world (CIA, 2013). While Malaysia is predominantly Malay and Bumiputra, the Chinese make up almost three fourths of Singapore's population, with Malays and Indians constituting small but significant ethnic minorities. Singapore had a similar history of British colonial rule. The British first gained a foothold in the island state in 1819 when an East India Company official, Stamford Raffles established a trading post there after reaching an agreement with the Johor Sultanate in Malaya. From then on the territory was gradually incorporated as a Crown colony and became a British Straits Settlement. For the most part, the colonial and pre-independence years of both countries were intertwined. However, besides the two years it was in federation with Malaysia from 1963 to 1965, Singapore was a politically separate entity under British rule. While Singapore was decolonised in 1963 when it formed the federation of Malaysia together with Sabah and Sarawak, it only formally gained its independence when it separated from the federation in 1965. Prior to the federation, it was administered as a Crown colony separate from the Malay states and ruled directly by the British. The British had for years tried to merge Singapore with the Malay hinterland as Singapore was an integral part of the Malayan peninsula, geographically, culturally and economically. However, fervent opposition from the rulers of the nine Malay states, who were wary that the move would pave the way for their kingdoms to be brought under direct British rule, 
ensured the merger did not materialise (Vasil, 2000). Hence, Singapore remained as a separate British Crown colony until 1963.

Unlike the case of Malaya (later Malaysia), nationalist and anti-colonial sentiments never really took off in colonial era Singapore post-World War 2. This late transition to decolonisation and independence compared to its neighbours can be attributed to the lack of a sense of national identity because the majority of the population were immigrants preoccupied with matters of trade and commerce (Vasil 2000; Milne \& Mauzy, 2002). As a result, unlike most states in the region, decolonisation in Singapore occurred was largely driven by the colonial power, Britain. With anti-colonial sentiments running high during the 1950s and 1960s and with the rest of the region gradually decolonising to become independent nation states, the British felt pressured to do the same with Singapore. At the same time, they did not want to completely lose control of Singapore as the territory was of considerable strategic importance to them. There was a significant amount of British and Western investment in Singapore. As such, the British authorities decided to undertake a process of decolonisation in Singapore without extending it full independence as a sovereign state. When Malaysia gained in independence in 1957, Singapore was still a British colony. It only gained its independence, albeit partially when it ceased being a Crown colony and became a part of the Federation of Malaysia together with Malaya, Sabah and Sarawak.

\section{The Merger}

When Singapore was decolonised in 1963, the People's Action Party emerged as the party that filled the political void. At its core, it was a radical anti-colonial movement that campaigned for complete independence from Britain. The PAP represented a broad coalition of social democrats and more leftist pro-communist elements in Singapore, who united under the banner of fighting for a sovereign Singapore (Milne \& Mauzy, 2002). The British were particularly worried that this pro-communist faction would eventually dominate the PAP. With communist insurgencies proliferating across Southeast Asia at the time, the British were worried that the same fate would befall Singapore. Adding to their worries was the existence of a communist insurgency in Malaya. To prevent civil unrest and 
ensure stability in its former colonies, British administrators revived the idea of a merger between both territories. A proposal of a federation was put forward to both the PAP and their counterparts in Malaya, UMNO. The Malay ruling class in Malaya were initially against the idea of a merger with Singapore. This was because they were afraid that the large immigrant population in Singapore would threaten the existing racial balance and therefore the political primacy of the Malays. While there were a significant number of Indians and Chinese in Malaya, more than half the population were still Malay. In Singapore on the other hand, the population was predominantly Chinese, with a significant number of Indians as well. Malays were a minority in Singapore. Wanting to preserve their political dominance, UMNO and the Malay aristocracy rejected the proposal at first. Eventually however, the British managed to persuade them to accept the proposal, due in no small part to the cordial relationship the British administrators had with the Prime Minister, Tunku Abdul Rahman, who was very pro-British (Vasil, 2000). It was also because the Federation was to include the British controlled-territories of Sabah, Sarawak and Brunei all of which had large populations of Malays and the other Bumiputra races. Part of the reason for this decision was to allay the fears the Malays had of non-Malay, particularly Chinese dominance through population numbers. While Brunei rejected the proposal, Sabah and Sarawak agreed to be a part of this new federation.

In Singapore, the idea of a merger began to receive more appeal, especially among the social democrat faction within the PAP. This was because they were afraid of the growing influence of the pro-communist elements in the PAP. There was already an internal struggle going on in the PAP ever since its formation, between the largely Western-educated and Western influenced social democrats led by 'Harry' Lee Kuan Yew, who would go on to become Singapore's first and longest-serving Prime Minister , and the Chinese educated working class members who sympathised with the communist struggle. Lee had already expelled a senior leader of the leftist faction, Lim Chin Siong prior to 1963. Lim went on to form the Barisan Sosialis or Socialist Front. The Socialist Front was opposed to the merger with Malaya started to gain support among the working class Chinese population, who were the dominant demographic at the time. At the same time, the Chinese educated socialists within the PAP were also trying to displace the Lee's social democrats from leadership 
positions. With almost three fourths of Singapore's population being Chinese, with many of them being Chinese educated, it was a fertile breeding ground for communist ideology to spread. Realising this and also the fact that the Western educated PAP leaders representing the middle and professional classes could not hope to gain the same kind of mass appeal that Lim Chin Siong and the socialists could amongst most of the Chinese population, the idea of a merger with Malaya looked increasingly appealing to Lee Kuan Yew. Lee realised the only way the PAP would be able to maintain power without a bitter struggle would be to join the Federation. This was because the Malayan government were fiercely anticommunist, and would not tolerate the idea of a Chinese led Communist movement to develop. The PAP, UMNO and the British shared a common enemy in the Communists and socialists, and as such merger talks began to take place between the three parties. In essence, both countries witnessed a consolidation of more conservative pro-establishment forces in opposition to the anti-establishment left.

\section{Operation Coldstore and the 1963 general elections.}

To prepare for the eventual merger with Malaya, the PAP together with the help of the British authorities initiated an anti-communist clampdown in February 1963 called 'Operation Coldstore', using the pretext of ensuring order and stability before the transition. The Socialist Front, which was considered a threat by the PAP, was one the main targets. Also targeted were the trade unions allied with the Socialist Front. Key members of the Socialist Front including its leader Lim Chin Siong were detained along with trade unionists, journalists and student leaders who were suspected of propagating socialist ideology (Milne \& Mauzy, 2002). The PAP proceeded to engage the support of the labour class by helping to form the National Trades Union Congress following the split of the Singapore Trade Union Congress to counter the influence of the Socialist Front allied trade unions. Those arrested were detained under the Prevention of Public Security Order or PPSO, which allowed for detention without trial. Detainees were alleged to have been involved in 'subversive' activities aiming to overthrow the PAP government and install a socialist state in its place (Jones, 2000). Operation Coldstore severely crippled the Socialist Front as most of its senior leaders were in prison and their remaining trade union allies were co-opted into the new PAP-friendly NTUC. As a result, the Socialist Front could not 
effectively challenge the PAP in the 1963 general elections held in September. Despite putting up a strong fight by winning 33\% of the vote and 13 out of 51 seats, government clampdowns and the arrest of its top leaders during Operation Coldstore allowed the PAP to claim victory in the polls, in spite of the latter having a poorer showing compared to the previous elections in 1959. The Socialist Front would continue its decline after that and cease to become a political force in Singapore. With the PAP's only real rival removed from the political equation, it paved the way for the Federation with Malaya, Sabah and Sarawak to go through. It also meant that the PAP's rule would largely go unchallenged and provided the party with the foundation to gradually entrench the political system in its favo

Table 1.5 Results of the 1963 General Elections in Singapore

\begin{tabular}{|l|l|l|l|l|}
\hline Party & Votes & $\%$ & $\begin{array}{l}\text { Seat } \\
\text { S }\end{array}$ & +/- \\
\hline People's Action Party & $\begin{array}{l}272,92 \\
4\end{array}$ & 46.9 & 37 & -6 \\
\hline Barisan Sosialis & $\begin{array}{l}193,30 \\
1\end{array}$ & 33.2 & 13 & +13 \\
\hline Singapore Alliance & 48,967 & 8.4 & 0 & \\
\hline United People's Party & 48,785 & 8.4 & 1 & +1 \\
\hline Partai Rakyat & 8,259 & 1.4 & 0 & \\
\hline Pan-Malayan Malaysian & 1,545 & 0.3 & 0 & \\
\hline Party & & & & \\
\hline United Democratic Party & 760 & 0.1 & 0 & \\
\hline Workers' Party & 286 & 0.1 & 0 & \\
\hline Independents & 6,788 & 1.2 & 0 & -1 \\
\hline Invalid/blank votes & $\mathbf{5 , 8 1 8}$ & - & - & - \\
\hline Turnout & $\mathbf{5 8 7 , 4 3}$ & 95.1 & 51 & - \\
\hline Electorate & $\mathbf{3}$ & & & \\
\hline & $\mathbf{6 1 7 , 4 5}$ & - & - & - \\
\hline $\mathbf{0}$ & & & \\
\hline
\end{tabular}


Source: Singapore Elections, n.d.

\section{Separation from Malaysia}

From the start of the merger with Malaysia, the relationship between both states was rocky. To begin with, Singapore was only allocated 15 seats in the 159 seat lower house of the new federal parliament, despite having roughly 17 percent of the federation's population (Vasil, 2000). This unequal representation meant that in practice there was not much difference between Singapore and the individual states that made up Malaya such as Selangor or Johor. Under the original proposal, Singapore was supposed to be an equal partner together with Malaya, Sabah and Sarawak as the four constituent entities that made up the Federation of Malaysia. Furthermore, in order for the merger to go through, Tunku Abdul Rahman insisted that Lee Kuan Yew agreed to an unwritten agreement that limited the political role of the PAP to within the boundaries of Singapore. In reciprocation, the Tunku promised that UMNO and the Alliance would not involve themselves in Singaporean politics. The political system of Singapore would be kept separate from the rest of Malaysia. This was a hard pill to swallow for Lee because his political ambitions for the PAP extended beyond Singapore. Unsurprisingly, these arrangements caused considerable dissatisfaction among Singapore's leaders, as they had hoped for a better deal. However, even though the terms were not in favour to the PAP, the very real threat of losing power to the Socialist Front led them to sign on anyway. The difference in opinion between Tunku Abdul Rahman and Lee Kuan Yew as well as the ideological differences between UMNO and the PAP were also major contributors to the split. The racial factor should also not be downplayed. UMNO leaders were still wary of a primarily non-Malay Singapore, even with the inclusion of the largely Bumiputra territories of Sabah and Sarawak into the Federation. Their fears of eventual Chinese dominance coupled with the PAP's national ambitions doomed the relationship from the start.

In spite of the earlier agreement on not interfering with each other's politics, the PAP eventually decided to contest in Malaya's general elections in 1964 as it was discontent with its predicament being in the federal opposition despite being the government in Singapore. This move infuriated UMNO, as the PAP would be contesting against Alliance 
candidates, directly challenging its rule in Malaya. Singapore wanted to play a bigger role in the Federation, while the UMNO leaders did not want the PAP's competing vision of a multiracial Malaysia bereft of special rights and privileges for Malays and Bumiputra races to take root especially among the country's significant non-Malay minority. Thus, relations between the Malay-dominated federal government in Kuala Lumpur and the primarily nonMalay Singaporean government took a turn for the worse, putting to bed any glimmer of hope there was that a more lasting and workable relationship between the two could still be developed. The PAP's decision to contest in elections across the causeway precipitated events leading to the 1964 racial riots in Singapore largely caused by UMNO backed instigators (Vasil, 2000). The resulting clashes between Chinese and Malay protesters escalated tensions between Singapore and Malaysia. Shortly after that the decision was made by Tunku Abdul Rahman in consultation with other members of the Alliance that the differences between the two were irreconcilable and in in August 1965 the federal parliament voted overwhelmingly for the cessation of Singapore from the Federation. Lee Kuan Yew though extremely saddened by this (he even broke down in tears when announcing Singapore's exit), realised that there was no other alternative. Singapore would have to chart its own path now, as an independent nation.

\section{Post-independence: building a new nation}

The riots and the experience of separation made Lee realise the dangers of communalism and how ethnic tensions if left unchecked could threaten the stability of a young nation. In light of those experiences, diversity management became a top priority for the PAP. Like Malaysia, it did not want to witness racial tensions spilling over into violent hostilities again. Unlike Malaysia however, Singapore chose a different path to multicultural management.

Despite having small Malay settlements before colonisation, the island gradually experienced an influx of immigrants mainly from Southern China and India soon after it was colonised by the British. Due to its relatively young history and the fact that at the time of independence in 1965 most of its population were made up of immigrants who arrived in the late $19^{\text {th }}$ and early $20^{\text {th }}$ centuries, there was no real sense of belonging to a unified Singaporean community. Communalism was still strong, especially among the Chinese educated section of the population. A common national identity had to be developed as it 
was vital for any new nation to succeed. The PAP had to build a national identity from scratch and chose not to have the culture of the dominant Chinese ethnic group as a base in which to derive this identity from. While Singapore wanted to put the two tumultuous years in the Federation behind them, that period exposed the dominant Chinese majority in the country to the intensity of Malay "feelings of indigenousness" and made them realise the importance of pursuing the idea of a multi-racial Singapore rather than a Chinese one (Vasil, 2000: p.5).

The PAP leadership understood the importance of developing social cohesion. Deliberate steps were taken in its early years of independence to ensure a neutral national identity was constructed whilst recognising the multicultural nature of Singaporean society. For instance, English not Mandarin or Malay was chosen as the primary language of instruction in schools and all government institutions. Consideration for minority races were taken seriously and provided for in the constitution. Under Article 152 of the Constitution of Singapore, the government had the responsibility to care for racial and religious minorities in Singapore as well as recognise the 'special position of the Malays' as indigenous peoples of Singapore. Article 152 also empowered the government to promote social and cultural interests of the Malays and the Malay language (Hill \& Lian, 1995). As such, the national anthem was in the Malay language, to recognise the history of the country as a Malay settlement before it was colonised and reassure the Malay minority that the government is serious about its efforts to ensure the culture of the Chinese majority does not impinge on Malay identity and that of the other minorities (Singh, 2006). In the same token, even though English would be the primary language used; Malay and Tamil, the mother tongue of most Indians in Singapore were gazetted as official languages in the country together with Mandarin. In the same vein, public housing was another vital area in which the government saw the opportunity to promote racial integration (Milne \& Mauzy, 2002). As a country with limited land, it was inevitable that the vast majority of the population had to be housed in high rise flats. In building residential high rises to house Singapore's growing population, the country's public housing agency, the Housing Development Board instituted an Ethnic Integration Policy in all public housing estates. Under the policy each block of HDB flats had to be allocated and sold to families based roughly in proportion to the racial make- 
up of the country (HDB, 2013). This move was made to promote racial integration and to prevent the development of racial enclaves and discourage the physical segregation of races (Vasil, 2000).

At the same time, for similar reasons employed by the Malaysian ruling elite i.e. ensuring ethnic differences do not conflagrate into instability, the PAP also chose to pursue a form of limited democracy instead of going down the route of Western styled liberal democracy. The argument was that Singaporean society was not ready for liberal democracy as civil liberties such as freedom of speech and freedom of assembly could easily result in communal feelings to flare up; threatening national unity and ultimately the stability of the young nation (Singh, 2006). Restrictions on civil liberties were therefore instituted based on the motive of limiting the influence of leaders and political parties that espoused communalism. The PAPs rationale was that restrictions were needed in order to curtail the ability of these movements from exploiting communal sentiments by pitting one community against the other. They were particularly worried that a Socialist Front type movement would re-emerge, threatening the new found political dominance of the PAP (Milne \& Mauzy, 2002). Similar to the Malaysian case, the anti-communist and anticommunalist argument was used. At the time, the paramount agenda was to engineer social and economic advancement, not transitioning to a more open political system. Like most countries that were decolonised during that time period, Singapore was relatively underdeveloped. In an atmosphere of lack and uncertainty, Lee and his compatriots in the PAP reasoned that exposure to 'subversive' ideas could spell to disaster for the stability of any new nation, especially when a nation's population is as multiracial as Singapore's (Hill \& Lian, 1995). With restrictions in place and controls on opposition activity, the Socialist Front quickly disintegrated (Vasil, 2000). Even though they participated in the 1963 elections and won a respectable number of seats in parliament, they refused to recognise an independent PAP-controlled Singapore and boycotted Parliament. The Socialist MPs in parliament gradually resigned and without the leadership of Lim Chin Siong who was in political exile or an equivalent leader, the party soon faded into the background (Milne \& Mauzy, 2002). By the time of the 1968 elections, it did not even matter that the party chose to boycott the elections as it ceased to be a relevant political actor by then. 
With the wounds of separation still raw and an aggressive Indonesian republic seeking to assert its role as a central power in the region, the new Singaporean republic had to deal with two less than friendly neighbours. This forced the PAP to develop a 'siege mentality' of sorts as Lee called upon Singapore's citizenry to support a comprehensive strategy for survival (Means, 1996). This strategy included the mobilisation of the nation's human capital and economic resources it had in order to ensure Singapore would be able to achieve progress and stability. Conscription was introduced through the National Service (amendment) Act in 1967. Under this provision, every able bodied male has to serve for a period of 2 years in the armed forces once he reaches 18 years of age and has to continue on active reservist duty till the age of 40 (Vasil, 2000). This measure fulfilled two important objectives. The first one was the need to build a substantial military force capable of defending the nation from external threats in a short amount of time. Given the uncertain climate were hostilities between neighbours were very overt, the government thought it imperative that Singapore should build up its military manpower in order to deal with this challenge. The other objective was to encourage social cohesion among the various races of the country. It was hoped that serving together in the armed forces would develop a sense of belonging for the future generations of Singapore; in fact the implementation of National Service was a key part of the PAP's aim to foster a sense of nationhood among the citizenry (Singh, 2006).

On the economic front, the PAP embarked on an ambitious industrialisation programme that centred on export oriented growth. Initially poised to serve as a manufacturing based for the Malaysian market, cessation meant that Singapore had to change its economic strategy or risk stagnation. Export-oriented manufacturing was seen as a viable option for promoting economic growth. To encourage export led investment, the Economic Development Board was created to devise the relevant industrial policies, akin to the role of the Japanese Ministry of International Trade and Industry. Statutory boards and state enterprises were also set up to enable the state to take an active stake in the economy (Hill \& Lian, 1995). Besides state investment, the government aggressively pursued foreign direct investment by providing a favourable investment climate for multinationals (Milne \& Mauzy, 2002). A significant proportion of state monies were ploughed into improving 
infrastructure and communications to facilitate business activities. Also, with the PAP taming the unions through the NTUC, labour costs were kept low. At the same time, the bureaucracy was also completely 'insulated' from social and political forces in the country, increasing efficiency and greatly reducing corruption (Case, 2002). Through these policies, the PAP managed to put Singapore on the fast track to economic development, achieving incredibly high and consistent growth rates throughout the $80 \mathrm{~s}$ and $90 \mathrm{~s}$, earning it the moniker of one of Asia's 'Tiger' economies. In less than a generation, Singapore was transformed from an economic backwater to an industrialised nation. This brought about massive changes in the socio-economic status of Singapore's citizenry. The middle class became the dominant demographic (Verweij \& Pelizzo, 2009). Similar to the case of Malaysia, the PAP's prowess in economic management allowed it to maintain voter support by delivering vast improvements in living standards as a trade-off for limiting civil and political liberties. Unlike UMNO however, the PAP did not need to practice patronage politics in order to maintain internal party cohesion, as most of its senior leaders were handpicked by Lee Kuan Yew for their capabilities rather than their grassroots support (Vasil, 2000). The lack of a patronage system minimised economic leakages and allowed Singapore to progress even further economically than Malaysia.

\section{PAP dominance}

As a direct result of all these undertakings, the PAP secured its political legitimacy. Having successfully brought order, stability and prosperity to its citizens, not to mention high levels of employment through economic progress it received a strong show of support in consecutive polls. In fact, in successive general elections from 1968 to 1980; a period of 12 years, the PAP won all the seats in parliament (Singapore Elections, n.d.). A fragmented and muzzled opposition posed little threat to the party and this allowed the PAP to consolidate its position of single party dominance. With links between the party and the machinations of government virtually indistinguishable as the bureaucracy was essentially fused with the party and the elections department was an agency under the purview of the Prime Minister's office, elections only served as a barometer of satisfaction on the party's rule, not as a competitive political tussle between other parties for control over the government. The 'limited democracy' that Lee Kuan Yew and his party faithful aimed for basically evolved 
into authoritarian rule through a single party dominant system. The dominance of the PAP in national politics surpassed even that of UMNO in Malaysia, as the latter still had tough electoral contests in certain regions of the country even during its peak of power under Mahathir. The combination of strict controls on civil liberties that greatly disadvantaged political opponents, a strong social cohesion agenda and the focus on promoting economic development made certain that the PAP could continue to solidify its position as the only relevant political party in the country for decades, essentially paving the way for the single party dominance as it stands currently.

\section{Chapter conclusion}

This chapter gave a brief but detailed snapshot of post-colonial history in Malaysia and Singapore and how authoritarian rule came to be in both countries. The respective ruling parties were initially formed as a platform to campaign for independence. Once that was achieved, both parties set about building up state capacity to meet the challenges of governing a newly independent nation. In the process of doing that, both parties consolidated their grip on power. Given the regional political landscape at the time, the threat of communism and ethno-religious communalism still loomed large in the minds of both UMNO and PAP leaders. The experience of racial riots and the communist insurgency only confirmed the dangers these elements had in threatening the stability and national unity of each country. In light of this, the ruling parties in Malaysia and Singapore chose to embark on a controlled or limited form of democracy instead of the Western liberal democratic model. Elections were held and the voting process was relatively free, but it was rarely fair. Measures were taken to limit political involvement by opposition parties. This included restricting freedom of speech, clamping down an opposition rallies, and from time to time arresting key opposition figures who were deemed to be too 'subversive' under detention without trial laws like the ISA.

The reasoning employed by both parties was that given that both countries had a multiracial population and were relatively underdeveloped at the time, it was surmised that this democracy with restrictions was necessary to support the national development agenda. Socio-economic development was the most important objective for both 
governments and only the elements of democracy which could facilitate this would be retained while civil liberties such as freedom of expression were seen as being potentially damaging to racial harmony, and could threaten economic progress and stability. Gradually, through the use of repressive laws, political opposition in both countries were kept in check to ensure they did not pose a threat to the political legitimacy of the incumbent parties. By the 1970s, the political system in both states had effectively become competitive authoritarian, with UMNO dominating the political process in Malaysia and PAP doing the same in Singapore. Strong state authoritarianism and an emphasis on economic development proved to be a potent mix for the durability of semi-democracy in both countries. 


\section{Chapter 2: Key factors promoting authoritarian stability}

As mentioned in the introduction, much of the literature on the resilience of competitive authoritarianism in Malaysia and Singapore emphasized the importance of elite forces and elite pacts. The importance of these elements can be clearly seen based on the historical narrative of strong state formation in the case study countries laid out in the previous chapter. Now that the historical background to authoritarian rule has been discussed, in relation to that, this chapter will look at the key factors that have served as sources of regime stability for UMNO and the PAP and have allowed the competitive authoritarian system to stand the test of time in both countries. This chapter will adopt a more analytical lense utilising the 'state capacity vs. civil society' framework stated in the introduction and will review the ways in which state dominance was exercised during the 'high' period of authoritarianism in both countries from the late 1970s to the mid-1990s. In particular the methods in which the respective ruling parties maintained rule and legitimacy in the context of weak democratic credentials will be explored in further detail.

\section{A: State strength}

This section discusses where state strength came from in Malaysia and Singapore and the ways in which state capacity was demonstrated. Most scholars of democratisation seem to agree that state strength or state capacity is an important aspect of regime stability. Indeed, states that have limited capacity or legitimacy tend to be more unstable than the ones who do. It is important to make the distinction between state strength and regime type. Not all democracies are strong states and not all dictatorships are weak ones. This can be seen in many states in Sub-Saharan Africa, where democracy has failed to be consolidated due to the the lack of state capacity, while authoritarian states like Saudi Arabia and the UAE manage to stay in power because they are strong states. State power or strength is a far more reliable source of political stability than just authoritarian rule, though it is much harder to build (Slater, 2012). Indeed Slater and Fenner opine that "a strong state is the best historical foundation for a durable authoritarian regime, not vice versa" (2011: p.16). 
Relating this back to the topic at hand, in contrast to most of the other states in Southeast Asia at the time, the structure and institutions that were needed in order to govern an independent nation were left largely intact in Singapore and Malaysia. This was because the decolonisation process in both countries did not involve armed struggle and the forceful ejection of the colonising powers from the country (Slater, 2012). It was a gradual, managed process that involved input from both parties i.e. the British and the local elites. This ensured the key institutions and structures needed to build state capacity were retained. This included a judicial system based on the British common law system that advocated the rule of law, a parliamentary system based on the British Westminster model, and a well organised bureaucracy (Slater \& Fenner, 2011). The existing structures and institutions allowed UMNO and the PAP to govern effectively when the British left Malaysia and Singapore. In this respect, Malaysia and Singapore were fortunate in that they inherited an already well developed state apparatus from the colonial power and hence were spared from the monumental task of building a state apparatus from scratch. Over the course of a few decades, state capacity in both countries were strengthened and reinforced from this strong base to maintain regime stability.

Based on the literature, it is clear that state strength was a crucial element that allowed UMNO and the PAP to hold on to power for so long. The ability of the state to provide clear national goals, deliver public goods and services, manage conflict and draw the resources required to carry out these functions from society allow the regime to maintain power and remain stable for a prolonged period (Grugel, 2000). The 'extraordinary strength of the state apparatus in both countries best explains why it has proved so stable and enduring on both sides of the Causeway' (Slater, 2012). This clearly shows why the single party dominant system has flourished in Malaysian and Singapore for such an extended period; in fact as it stands now both parties still enjoy an unhindered position of political primacy in their respective political systems, though UMNO's position is a lot more vulnerable now than it was before. As mentioned before, while state power does not necessarily equate to authoritarianism, having a strong grip on institutions have allowed both ruling parties to consolidate authoritarian rule. This is precisely the case in Malaysia and Singapore. UMNO and the PAP have directly tied the development of a strong state with that of their 
respective political parties. The close links between the ruling party and the state in both countries have meant that a strong state apparatus translates directly to party control of state structures and institutions.

At the outset of independence, the civil service in both countries had no special affinity to nationalist struggles due to heavy exposure to British colonial customs, traditions, rules and norms. The bulk of the important positions in the service were besides being helmed by British officers, were mostly made up of Anglophile locals and immigrants from other British colonies. This was more so in Singapore than in Malaysia. As a result, one of the first things the PAP leaders did when they assumed power "was to seek to drastically alter the attitudes of civil servants and give them a new sense of dedication and commitment to Singapore" (Vasil, 2000 p.54). Similarly in Malaysia, UMNO sought to address the racial imbalance of the civil service as most positions of responsibility were held by ethnic Indians, Sri Lankans and the Malay aristocrats with very little representation from the indigenous Malay middle class (Crouch, 1996). Gradually, through the reconstitution of the civil service in Malaysia to enhance Bumiputra representation and the imparting of political education to new civil service recruits, the lines between party and state have become almost indistinguishable in both countries. Decades of rule have essentially led most if not all institutions of the state to be strongly influenced by the dictates of party leadership. The 'fusion' of top levels of the public sector with that of the party have allowed both ruling parties to cement their incumbent advantage (Vasil, 2000; Crouch, 1996).

The 'infrastructural power' exercised by the UMNO and PAP-led governments allowed both parties to fulfil various political goals, not just the maintenance of authoritarian rule (Slater \& Fenner, 2011). National progress through growth and industrialisation was now possible. After blurring the boundaries between party and state by fusing party interests with that of state institutions, the ruling parties in Singapore and Malaysia proceeded with the adoption of the developmental state model where national priorities were set primarily upon an economic development and industrialisation agenda. This further reinforced regime stability. After having secured order in the early years of their respective country's independence through an adept civil service and capable law enforcement agencies, the ruling parties in both states turned to achieving economic progress in order to win the 
hearts and minds of the citizenry. As a strong state is a state that is able to meet its obligations to its citizens through securing order and progress, it was only natural that the focus of both UMNO and the PAP were concentrated towards achieving a reasonable standard of economic prosperity for their respective populations once order was secured after the threat of communism and racial tensions were stoked (Milne \& Mauzy, 2002). The developmental state model of state-led macroeconomic planning that was adopted by Malaysia and Singapore would have been impossible to undertake in a weak state which lacks the power to tax and regulate the economy and to withstand political and social challenges. It was only through having a well-developed state apparatus that UMNO and the PAP could embark on a strong state-led economic and industrial development programme.

Having a strong state meant that those national development objectives could be fulfilled. As both countries were relatively poor and underdeveloped at the time of independence, state strength and state capacity proved to be integral for the future development of both states. At the time of independence, Malaysia's GDP per capita was roughly equal to that of Ghana. While Singapore had a marginally better GDP per capita, it was still a poor country with limited infrastructure and capital (Abraham, 1997; Chan et al., 1987). This plus the multi-religious and multi-ethnic nature of both countries and the existing ethnic tensions there meant that stability could have easily been affected. Without a strong state apparatus to aid the newly formed governments to govern, maintaining order would have been a challenge. National development would have had to take a back seat for the maintenance of order and stability (Case, 2002). While there were teething law and order problems in the decade and a half after independence in the form of racial riots and communist/socialist agitations, the ruling parties and indeed the countries as a whole went through this phase relatively unscathed. In fact both parties had solidified their legitimacy after these episodes. Once order was restored after that brief period of violence, UMNO and the PAP correctly understood that the maintenance of law and order would not be enough to convince citizens to vote for them come election time (Means, 1996). Greater prosperity would remedy the grievances of the population and alleviate ethnic tensions. Understanding this, and having the capacity and resources to undertake a national development agenda, both 
governments proceeded with an economic industrialisation plan. By successfully embarking on an industrialisation programme that lifted many citizens out of poverty and created a new middle class, UMNO and the PAP gained new levels of confidence and legitimacy from the citizenry, translating to ballot-box returns for both parties. This segued conveniently into other main objective of both ruling parties: maintaining incumbency.

State strength and state capacity were important components that ensured regime stability. The resilience of the regime was dependent upon a strong state apparatus that could enforce its rule and maintain legitimacy. State power, which is the influence exercised by the ruling party through control of the state apparatus, provided mechanisms for the incumbent party to sustain authoritarian durability through the coercion of rivals, the extraction of revenues, and the cultivation of dependence (Slater \& Fenner, 2011). In the case of UMNO for instance, the coercion of political rivals by either jailing key opposition leaders under preventive detention laws or forcing them into a political alliance with the National Front coalition; as was the case with Gerakan and the PPP in the 1970s and briefly with PAS in 1974, allowed it to sustain its incumbency and fracture political opposition. The ability of the party-controlled state to extract revenues and exercise fiscal authority also goes a long way in ensuring the state remains under the control or at least under the influence of the party. High extractive capacity means that the government is able to take full advantage of the rise in the country's wealth that would otherwise only benefit private capital through well-developed tax collection mechanisms (Slater \& Fenner, 2011). Besides efficient tax collection mechanisms, control over state investment arms such as Khazanah Nasional in Malaysia and Temasek in Singapore that hold a substantial number of assets and resources numbering in the billions of dollars has considerably enhanced the power (fiscal) of both parties. UMNO and the PAP's adeptness at revenue collection has resulted in a well-oiled government and party machinery that continues to maintain the fiscal advantage over society and by extension its political rivals even as they become wealthier.

In terms of cultivating dependence, having an extensive state-provision for services enhances state legitimacy for instance, even if it does not necessarily translate to citizen loyalty. By successfully providing important services such as education and healthcare, the 
state has negated the influence of non-state organisations in connecting with the masses and gaining widespread credibility as those organisations are at their most active in the absence of state provided public services. The provision of public services also allows the state and by extension the ruling party in areas such as education can play a powerful role in socializing citizens into political dormancy (Slater \& Fenner, 2011). The school history syllabus for example has downplayed the role of the left-leaning political movements that were at odds with UMNO and the PAP in the independence struggle of both countries in favour of more importance placed on the role of the ruling parties in gaining independence and developing the country. By overstating the historical legitimacy of the incumbent party, citizens are reminded of the integral role of the party in developing the country and are less inclined to engage with the political opposition and vote for them (Slater \& Fenner, 2011; Slater, 2012).

The control of top levels of the civil service and other institutions such as the police force with that of party leadership control over state institutions meant that the ruling party could maintain incumbency relatively easily as the electoral arena was set to its favour. Having a strong state apparatus allowed the ruling parties in Malaysia and Singapore to effectively clamp down on dissent through the use of law enforcement agencies for instance. The police force while professing to be neutral, are closely linked to the top levels of party leadership. While this relationship may be less pronounced in Singapore, this is not the case in Malaysia, where 'yes men' are successively appointed to the Inspector General of Police position, have cordial relations with senior party officials and are rewarded with lucrative positions in government linked companies or government contracts once they retire (Stewart, 2003). This co-option of senior leaders in key state institutions by UMNO has allowed it to take full advantage of its position by having a formidable state apparatus at its disposal. The ways in which both parties used this advantage will be discussed in greater detail under the 'dirty tricks and manipulation' section.

\section{B: Strong Leadership}

In addition to state strength, it is important to note that strong leadership was a key feature during the heydays of authoritarianism in Malaysia and Singapore. It was during the period 
after the ascension of Mahathir Mohamad to the prime minister's post that the single-party dominant system entered its most authoritarian phase and this was in no small part due to the premier's iron-willed leadership (Milne \& Mauzy, 1999). Similarly, without Lee Kuan Yew, competitive authoritarianism would not have been consolidated to the point it is now in Singapore. While there were other leaders who played a role in developing and consolidating stable authoritarian rule such as Tun Razak in Malaysia and Goh Chok Tong in Singapore, it was Mahathir and Lee that extended the depth and the reach of UMNO and the PAP's dominance in state affairs. In relation to that, this section will be focussing on the leadership roles played by these two in strengthening authoritarian rule and preserving re and regime stability in their respective countries through building-up state capacity and cracking down on opposition and civil society movements.

\section{Mahathir Mohamad and the consolidation of Authoritarian rule in Malaysia}

When Hussein Onn, Malaysia's third Prime Minister died in 1981, he was replaced by his appointed deputy Mahathir Mohamad. This marked the beginning of a period of authoritarian consolidation by the latter. Mahathir was a firebrand politician during his early days in UMNO. He was a very vocal defender of Malay rights and rose quickly through the ranks, becoming a member of the party's Supreme Council, its highest decision making body by the time the politically altering events of 1969 occurred. Despite his popularity with the party grassroots, he had a very tumultuous relationship with Tunku Abdul Rahman, the UMNO president and first Prime Minister. Mahathir heavily criticized the Tunku for his handling of race relations and argued that he was not doing enough to safeguard Malay interests. In the wake of the 1969 riots, his criticism of Tunku Abdul Rahman intensified. He was expelled from UMNO following this; however the damage was already done. It was these persistent attacks from Mahathir that played a major role in the Tunku's downfall and resignation as Prime Minister in 1970 (Milne \& Mauzy, 1999). Mahathir on the other hand was readmitted into UMNO when Abdul Razak succeeded Tunku as the Prime Minister and subsequently took on key ministerial portfolios in Education (an important portfolio for

future Prime Ministers) and later Trade and Industry before being appointed as Deputy Prime Minister under the leadership of Hussein Onn. While his predecessors initiated 
patterns of authoritarian style rule, under Mahathir, the single party dominant system was entrenched even further (Stewart, 2003).

The National Front and UMNO in particular gradually began to exercise a greater degree of influence over institutions of the state under his leadership. Party control of key state institutions were strengthened. The judiciary, which was previously marginally independent, was brought under control through coercion and manipulation (Stewart, 2003). The legislature, which was never as important as the cabinet and the executive in the first place, saw its importance diminish even further under Mahathir's rule. The pattern of huge electoral victories by the BN ensured that the federal parliament was firmly under the grip of the ruling coalition. The most important deliberations regarding key legislative and policy changes were done at the cabinet level, with Mahathir steering most of the proceedings (Wain, 2009). By the time of the 1990 elections which was another decisive victory for the ruling coalition, Mahathir emerged as the most dominant figure in Malaysian politics, essentially becoming an institution by himself after almost single handedly overcoming three rival centres of power: the royal institution, opponents within UMNO and the judiciary (Milne \& Mauzy, 1999). Malaysia is a constitutional monarchy and while the role of the Supreme Ruler or Agong is largely ceremonial, he does have certain powers he can exercise without the advice of the cabinet. The Agong is elected among the rulers of nine states during the Conference of Rulers once every five years. The ascension of an independent minded Agong who openly disdained Mahathir's methods triggered Mahathir to close any constitutional loopholes that could be used by the Agong to make life difficult for the Prime Minister (Milne \& Mauzy, 1999). Mahathir and UMNO set on a campaign to limit to redefine the constitutional powers of the Agong and the Conference of Rulers, with the intention to make their powers more limited and easier to predict. While not emerging completely victorious, he was and is the only Prime Minister who successfully challenged the authority of the royal institution and stripped them of key powers, despite not having unanimous support within his party over the issue (Crouch, 1996).

He met internal challenges within UMNO during the late 80 s with equal vigour. Unhappy over Mahathir's treatment of the royals and displeased with issues relating to patronage, a rival faction made-up of senior leaders within the party emerged to challenge Mahathir's 
faction. What ensued was a three year long struggle that saw the split of UMNO in 1987 and the formation of a political party from the rival faction called Semangat ' 46 or Spirit of '46 in reference to UMNO's formation year that contested the 1990 elections (Milne \& Mauzy, 1999). During this time, Mahathir also ran into trouble with the judiciary as the Federal Court, the nation's highest court declared the UMNO organisation to be illegal because of the split. Mahathir responded by sacking the Chief Justice and all the senior judges who ruled against him and proceeded to replace them with a new bench of handpicked successors, thus severely compromising judicial independence. The new Federal Court bench subsequently overturned the previous ruling and allowed Mahathir's faction to regain full control of the UMNO name and all resources attached to it (Crouch, 1996). Having won the battle for UMNO, he quickly saw off the challenge posed by Semangat 46 at the ballot box. The rival organisation was eventually disbanded and most of its members were later pardoned and reintegrated into UMNO by Mahathir. These political victories were key to Mahathir's attainment of such power and influence as it ensured that the power and authority he held as party president and executive superseded that of any other state institution, including the palace and the royal institution which was deeply respected by the vast majority of the population and especially the rural Malay heartland (Stewart, 2003).

This allowed his time as Prime Minister to go unchallenged from then on until the 1998 post-financial crisis 'Reformasi' or Reformation movement triggered by his sacking of Deputy Prime Minister and former protégé Anwar Ibrahim. Mahathir had a fall-out with Anwar over disagreements on how to handle the economy following the financial crisis in 1997. Anwar was a popular leader within the UMNO ranks as well as among the young Malay voters and had strong conservative credentials as he was a former leader of the influential Islamic Youth Movement or ABIM (Stewart, 2003). Realising that Anwar posed a threat to him, he removed him from all his posts in the party and the cabinet. Disgruntled, Anwar and his supporters took to the streets under the battle-cry of 'Reformasi'. He managed to gather large crowds of Malays to his cause. It was a time of economic crisis and with a strong challenger to Mahathir's incumbency in the form of Anwar, the political climate was ripe for a change in government (Wain, 2009). However, even at this point in 
time when Mahathir faced his most serious challenge to his political authority and legitimacy, he still maintained control over UMNO and despite sustaining electoral losses in some Malay majority seats he led the National Front to a convincing two-thirds majority victory in the 1999 general elections over Anwar Ibrahim's newly formed People's Justice Party and its allies in the Barisan Alternatif or Alternative Front. Anwar was subsequently arrested under the Internal Security Act and jailed under politically motivated corruption and sodomy charges. Mahathir's successful removal of all his rivals from the political arena ensured the continued viability of competitive authoritarianism where a weaker leader would have succumbed to societal pressures to democratise (Milne \& Mauzy, 1999).

\section{Stable authoritarianism under Lee Kuan Yew in Singapore}

The PAP has ruled Singapore without interruption since 1959. A large reason for that is due to the leadership of Lee Kuan Yew. A Cambridge trained lawyer from a relatively prosperous English educated family, he formed the PAP with a disparate group of leaders in 1954 . From the outset, Lee was a strong-willed leader. He managed to bring together different factions and interests groups under a common umbrella to pressure the colonial authorities for independence. The PAP was a loose coalition of English educated social democrats and Chinese educated pro-Communists and was formed as a mass-based, left wing organisation to mobilise against colonial rule under the British (Vasil, 2000). Lee was an instrumental figure in Singapore's short-lived federation with Malaysia. Despite significant opposition from the Barisan Sosialis which had widespread mass support and indeed from elements within his own party, he managed to see through the merger with Malaysia. When the proCommunist elements within the PAP subsequently left to form the Barisan Sosialis under the leadership of Lim Chin Siong, Lee's leadership ensured that the PAP did not suffer a further loss of support. This was integral in the PAP's electoral victory in the countrydefining 1963 general elections. It was through this victory that the PAP cemented its position as the nation's dominant political party as the Barisan Sosialis gradually crumbled after the elections following a prolonged crackdown on its leaders initiated by Lee.

Having to stave off competition from the Barisan Sosialis as well as convince the public on the merits of a merger with Malaysia, Lee demonstrated extraordinary resolve in achieving 
his goal of a federation with Malaysia while leading the PAP in defeating the Barisan Sosialis at the ballot-box (Milne \& Mauzy, 2002). During the difficult years of the merger where threats to the nation's stability in the form of racial riots surfaced, he acted decisively in turning to the security agencies with the help of Malaysia to quell the violence and restore order. After separation from Malaysia, it was largely due to Lee's leadership that a newly independent, resource poor nation without a cohesive national identity was transformed into an Asian Tiger with high levels of growth and industrialisation. While shoring up public support for the PAP through good governance and economic development, Lee at the same time also consolidated authoritarian rule through the PAP by clamping down on any political dissent (Chan, et. al, 1987). Following the lines of Operation Coldstore in the 1960s, Opposition leaders were persecuted in the 1980s and 1990s with arrests under preventive detention laws and making them bankrupt through defamation suits. An example of this was the case of his notable political nemesis, Worker's Party leader JB Jeyaretnam was harangued with court cases against him and had to ultimately leave his parliamentary seat after he was declared bankrupt after failing to pay damages to the PAP from the result of a libel suit (Mutalib, 2000).

As an authoritarian leader in a surface-level democracy, Lee was a key proponent for the notion of 'Asian Values'. He argued that Western styled liberal democracy was not suitable for Asia's developing nations as it could not guarantee stability and order. This concept was quickly seized upon by other authoritarian leaders in East Asia such as Mahathir Mohamad as a strong counter argument against consolidating democratic practices in the region (Milne \& Mauzy, 2002). He stressed through cultural influence such as the Confucian ethic, Asians in general were more predisposed to single-party rule rather than political pluralism. He particularly emphasised that in an Asian society, the notion of filial piety, that is the loyalty to one's family, corporation and country outweighed an individual's desire for personal freedom. The 'Asian Values' concept fitted in very well with Lee's vision for a prosperous Singapore with the PAP at the helm (Chan et al., 1987). While this concept was hardly universally accepted even within Singapore itself, it gave Lee and the PAP the intellectual and philosophical justification to continue with authoritarian rule even after the country became an industrialised nation in the 1980 s. 
Lee was Prime Minister for more than three decades and during that time he succeeded in strengthening authoritarian rule in the country despite massive societal changes following Singapore's transformation to a developed nation. He succeeded in balancing the needs and aspirations of the general population for economic freedom while preserving regime stability and incumbency. He laid the foundation for and expanded upon the single party dominant system in Singapore. By decisively dispatching the Barisan Sosialis in the early years of independence and maintaining PAP dominance in the following decades through the gradual 'marriage' of the party with the state, all while steering clear of patronage style politics practiced in Malaysia, he ensured the extraordinary resilience of the competitive authoritarian system in Singapore (Chan et al., 1987). Unlike Mahathir in UMNO, the PAP's legitimacy was never challenged during Lee's reign. This also made for a smooth transition process when Goh Chok Tong took over the reins of power in November 1990.

Linking all this back to the analytical framework, these developments can help explain why elite level manipulation was so important for the perpetuation of the single party dominant system in Malaysia and Singapore. Elite cohesion helped foster and build-up state capacity. This strong state apparatus was then utilised by the ruling parties to prevent the opposition and civil society movements from growing and gaining social capital (Case, 1996).

\section{C: 'Dirty tricks': Menu of manipulation}

While the previous sections focussed on the role state strength and strong leaders in preserving regime stability, this section looks at how the ruling parties in both states influenced key institutions like the judiciary and the police force to curtail opposition movements and manipulated elections through the use of their extensive resources to heavily favour incumbent rule in order to maintain their grip on power. In order to maintain power for prolonged periods, the ruling party has to be adept and skilful in utilising the 'menu of manipulation' at its disposal to ensure it wins election after election (Schedler, 2002). In this regard, the PAP and UMNO are skilled operators in the game of maintaining incumbent rule. 'Dirty tricks' are a key feature of competitive authoritarian states and the ruling parties in Malaysia and Singapore are no different (Case, 2002). 
As mentioned a few times before throughout the course of this paper, the ability of the both parties to sustain authoritarian rule by using state institutions to limit the effectiveness of the political opposition is an important reason why there has been no change in government in either country since they received independence. Control over the judiciary and the police force for example allows the ruling party to manipulate outcomes in instances where it could dent its credibility to be in its favour instead. This has happened numerous times in court cases against both UMNO and PAP interests. A notable example would be the overturning of a previous Federal Court ruling in Malaysia that declared UMNO to be illegal in the wake of the 1987 UMNO split through the removal of the Chief Justice and the bench of the court and installation of regime-friendly judges by Mahathir. In the course of doing that, judicial independence is compromised. While there are cases which clearly show that Malaysian courts have failed to uphold the rule of law, in the case of Singapore, the relationship between the judiciary and the executive is more discreet. Singapore has a reputation of upholding the rule of law and that has attracted many foreign businesses to set-up shop there. Despite this reputation, it is very rare that decisions made by the country's courts in cases involving PAP interests have gone against it (Mutalib, 2000). Instead, the PAP has utilised the courts and the legal system to go after its political opponents through the aggressive use of libel laws. Almost every major opposition figure has been slapped with a defamation suit by the PAP and damages often times amounted to hundreds of thousands of dollars. As the amount is too steep for most of them, more often than not they are declared bankrupt and required to step down from their parliamentary seat should they hold one (Ortmann, 2011).

The practice of using the security force to arrest social activists and opposition leaders is another tactic in the 'menu of manipulation' often employed by the ruling party to curb its critics and hinder the consolidation of the opposition. Preventive detention laws are utilised a great deal to facilitate the arrests of these individuals. Both Singapore and Malaysia have their version of the Internal Security Act that allow for this and have been extensively used especially during the 1960s and 70s under the guise of curbing the communist threat and preventing another racial riot (Case, 1996). While it has been rarely used in Singapore in recent times as the PAP prefers to use the more sophisticated route of libel suits against 
opponents, preventive detention is still employed by Malaysian authorities. During 'Operasi Lalang' in 1987 a total of 106 people, primarily opposition and human rights activists were arrested using the ISA under the pretext of preventing racial tensions between the Malays and Chinese from flaring up as result of the provocations between UMNO Youth and the various ethnic Chinese organisations (Wong et al., 2010). While Malaysia has recently done away with the ISA, other preventive detention mechanisms such as the Emergency Ordinance and laws with broad and ambiguous provisions for arrest such as the Sedition Act still exist and can be used to lock-up political dissidents.

Besides the usage of the judiciary and the security force to curb dissent, control over the media through state-run or state-connected media groups ensures that opposition politicians rarely get media coverage and in the instances when they do get coverage, it is mostly negative. This practice has meant that the policies and campaign platform of the opposition fail to reach a nationwide audience. Reporting bias in favour of the ruling party in the mainstream media heavily disadvantages opposition parties especially in the lead up to elections (Levitsky \& Way, 2010; Wong et. al., 2010). In most democracies where all political parties are given equal air-time to promote their policies and manifestos just before elections, there is no air-time given to opposition candidates on TV in Malaysia and Singapore. In addition to that, government censorship of the media is enforced through laws such as the Printing Presses and Publications Act (PPPA) in Malaysia and the Undesirable Publications Act (UPA) in Singapore (Case, 2002). These laws serve the purpose of monitoring the editorial content of newspapers and other mainstream publications and prevent the spread of 'subversive' information. In a heavily muzzled media environment, objective reporting regarding the ruling party is far and few between. As a result, a large section of the populace also buy in to the virtues of the ruling party and are wary of an opposition regularly painted as troublemakers and instigators by the media. This is especially true in Malaysia, where a significant swath of the population is located in rural areas with limited access to alternative of media and internet.

Putting aside the use of the legal system and the security forces to hinder opposition activity as well as restricting access to media, manipulations in the electoral arena are the biggest trump card the ruling party has in maintaining its power and preventing a change of 
government from occurring. For starters, the independence and impartiality of the election authorities in both countries come into question as they fall under the direct purview of the Prime Minister's Department in Malaysia and the Prime Minister's Office in Singapore respectively. Being placed under the organisational structure of the executive instead of being a stand-alone independent state institution compromises its independence (Mauzy \& Barter, 2008; Ortmann, 2011). The head of the Malaysian Election Commission is appointed by the Agong. However in practice it is the Prime Minister who vets candidates and 'advises' the Agong on appointments, as such those appointments become more partisan in nature (Lim, 2002). In fact, there were substantial allegations that both the Chairman and Deputy Chairman of the Election Commission were registered members of UMNO. The seven members that currently make up the EC were senior members of the civil service, an institution that has been heavily influenced by the ruling party (Jo Ann, 2013). In Singapore, the body in charge of overseeing elections is the Elections Department. It too has been accused by opposition politicians and political rights activists of not being impartial and politically separate from the ruling party. The Prime Minister still maintains control over the Election Department. While blatant vote rigging is not practiced in either country, the electoral system is hardly fair with the lack of structurally independent election authorities (Freedom House, 2013). Instead, the practice of gerrymandering through periodic electoral constituency delineation has been the chosen tactic employed by the election authorities under the auspices of the ruling parties to hinder any strong electoral challenge from the opposition. Gerrymandering, the process of redrawing electoral boundaries in a way that allows the incumbent to have an unfair advantage; has ensured the 'tipping point' for a change in government to take place through the ballot box remains impossibly high.

The delineation exercises carried out in both countries have helped foster incumbent rule. This is especially true in Malaysia, where the democratic 'one man, one vote' principle has not been adhered to when constituencies are redrawn. Limits placed on the maximum size difference between constituencies were completely removed in 1973, resulting in glaring discrepancies in size between certain constituencies. The largest constituency, Kapar for example has 10 times the number of voters than one of the smaller constituencies, 
Putrajaya (Jo Ann, 2013). It comes to no surprise that Putrajaya is considered a safe-seat for the National Front while Kapar has been an opposition seat for the two most recent general elections. Despite Malaysia being a highly urbanised nation, there are more rural and semirural constituencies than there are urban ones. Opposition support is at its strongest in the urban areas while the ruling coalition considers most rural and semi-rural seats to be 'safe areas'. These electoral arrangements mean that UMNO and its allies can technically eke out a simple majority in parliament even if it lost in all the country's urban constituencies where most of the population resides (Ostwald, 2013). In the most recent 2013 general elections for instance, UMNO lost in most of the urban seats but still won $60 \%$ of all parliamentary seats despite having secured only $47 \%$ of the vote (Welsh, 2013). As long as the EC is empowered by UMNO to maintain the current status quo heavily favouring incumbency in constituencies held by the ruling coalition, the durability of the single party dominant system will be hard to challenge.

In the case of Singapore, the introduction of Group Representation Constituencies or GRCs have also helped the PAP maintain its incumbency and hindered a credible opposition challenge from emerging for so long. GRCs are constituencies where elections are contested between groups as opposed to individual candidates. The GRC system was introduced in 1988 as a measure to ensure minority representation in parliament as at least one of the MPs in a GRC has to be from the Malay, Indian or other minority ethnic community. The size of each team has to be between three to six candidates according the Parliamentary Elections Act (Vasil, 2000). Today, the majority of MPs in parliament come from GRCs and single member constituency MPs constitute only 12 out of the 87 elected MPs. The existence of the GRC system has raised the bar for opposition candidates to contest in elections. Most opposition parties are small and lack the resources and manpower in order to field a team for the GRCs. The substantial deposit required for contestation and the higher threshold of votes required by the opposition in order to gain votes has served as a barrier that has resulted in many GRCs being uncontested by opposition candidates (Singh, 2006). Due to this, many walkovers are declared and the PAP teams win by default. It was only in the most recent 2011 general elections that an opposition party has managed to win a GRC. In that election, the Worker's Party contested in the Aljunied GRC and managed a 
considerable feat by defeating the incumbent PAP team that included a senior cabinet minister (Ortmann, 2011). Despite this achievement however, the cards are stacked against opposition parties due to this system and it would be a considerable challenge for the Worker's Party or any other opposition party to repeat this feat in the 14 other GRCs due to the high barriers to entry.

In addition to electoral manipulation and biased institutions, in Malaysia's case: government's usage of ethnic based politics as a tool to maintain its grip on power should also be noted. While both Malaysia and Singapore are competitive authoritarian states with diverse populations, the one key difference between the two is how this ethnic diversity is managed. Race and religion feature a lot more in the political considerations of Malaysia's ruling elite. Singapore's ethnic cleavages that were very apparent during the early years of independence have since become less important. By pursuing non-race-based political governance and a racially inclusive national identity, the centrality of ethnicity in political considerations gradually diminished to the point where it is not a prominent topic of national debate anymore. In contrast, ethnic issues are still political hot-button topics in Malaysia due in no small part to the ruling coalition's maintenance of political parties that run along ethnic lines (Cheah, 2004). With respect to that, UMNO's dominance depends upon the support it gains from the Malay majority. It has appealed itself to conservative Malay voters by branding itself as party that would defend Malay political and economic interests. In doing this, there were times where UMNO leaders would play up ethnic sentiments, sometimes dangerously skirting the lines of promoting ethnic hostilities with non-Malays, in order to maintain the support it enjoys from the Malays. UMNO's National Front allies the MCA and MIC would then try to appease the non-Malay voter base by reiterating the track record of the coalition in providing stable government and economic progress for all. This 'divide and rule policy' helped the ruling coalition in Malaysia to maintain its grip on power by playing one ethnic group off the other during occasions when it feels it needs to gain some political capital (Saravanamuttu, 2004). Due to this fragmentation of ethnicity, there was a lack of social capital as the opposition movement was also fragmented and civil society movements also failed to gain traction (Cheah, 2004). 


\section{Summary}

Manipulation of the judiciary, the use of coercion, media restrictions, an electoral system that is biased towards the incumbent party and still-present ethnic divisions in the case of Malaysia present heavy obstacles to the consolidation of opposition forces in both countries. The skilful manipulation of institutions and resources through the use of 'dirty tricks' has allowed UMNO and the PAP to sustain single party dominance in their respective political systems. This coupled with high state capacity and having strong-willed authoritarian leaders for a prolonged period resulted in competitive authoritarianism and with it the single-party dominant system to be entrenched. This ties in with Case's argument that emphasised elite pacts and elite control over the political process as the primary driver of regime resiliency. The ruling elite in both countries seemed to be dominantly in control up until the late 1990s. The strong state and the lack of social capital through a fractured opposition movement helped UMNO and the PAP maintain incumbent rule. Even in recent years where societal pressures to democratise have increased and opposition movements have started to gain more traction, the institutional arrangements in place has allowed them to withstand these pressures. However, it remains to be seen whether further demands for change can be withstood. An important point to note about strong authoritarian states is that while it is difficult for greater democracy to take root, once that 'tipping point' of societal demands and opposition pressure for regime change has been achieved, the democratic transition process will be relatively smooth and stable. This is largely because the institutions that support democratic governance albeit tainted by executive interference are already in place. The following chapter will look at the recent changes in the political landscape and whether the institutional arrangements discussed in this chapter will be enough for UMNO and the PAP to prevent a change in government. 


\section{Chapter 3: Recent developments and Prospects for Change}

This chapter looks at the recent political developments in Malaysia and Singapore and how this has impacted upon the resilience of the competitive authoritarian regimes there. While the previous chapter explored the sources of regime stability, this chapter will look at the factors that have spurred on the democratisation process in both countries. Again, using the state strength/state capacity vs. emerging civil society/opposition framework derived from the literature, the prospects for democratic transition will be explored. In Malaysia, the political landscape has altered significantly since the 1997 financial crisis. The middle class has become more politically aware. In relation to that, the civil society and the opposition movements have become much stronger. In the process, the credibility of the Barisan Nasional government has been gradually declining as the use of 'dirty tricks' and state capacity to influence political outcomes has become even more apparent to the general populace. The key shift witnessed from the 1997 crisis onwards was the increasing prominence of national level issues concerning corruption, cronyism and abuse of power by the ruling elite vis a vis race-related issues that generally were in favour of the ruling coalition. In the case of Singapore, the crisis did not affect the ruling elite there as much as it did in Malaysia. In fact, the political fall-out from the financial crisis was minimal. Singapore did however witness a gradual awakening of the middle class as newer generations began to tire of the 'nanny state' that exerted too much control over personal liberties. In response to that, reforms were instituted in order to be responsive to these demands. These measures allowed a greater space for civil society and the opposition movement to grow and become stronger. In light of all these developments, this chapter will look at the similarities and differences in the recent political developments that have affected the respective ruling parties and how this translates to regime resilience. 


\section{A: Malaysia}

\section{Asian Financial Crisis, Reformasi and Badawi Years}

During the fallout from Asian Financial Crisis in 1997, significant changes to Malaysia's political landscape occurred. His deputy Anwar Ibrahim was removed from all his party and cabinet positions in 1998 following a highly publicized spat between him and Mahathir. Anwar proceeded to protest this decision by initiating the Reformasi movement and forming his own political party called 'Keadilan' or the Justice Party. He formed a loose coalition with PAS, and the DAP to challenge Mahathir at the polls. Responding to these developments, Anwar's Reformasi movement was met with a decisive crackdown by the authorities. Anwar was subsequently jailed under trumped up charges of corruption and illicit sexual activity in 1999, months before a general election was scheduled (Mauzy \& Barter, 2008). Despite his jailing, Anwar still had popular support among the Malay youth and middle class, and his alliance with PAS which had considerable support in the northern Malay states threatened to eat into the UMNO's own vote bank. In addition to this, the unravelling of instances of corruption and nepotism involving senior leaders in UMNO and Barisan Nasional at a time when the nation was going through an economic crisis did not aid the cause of the ruling coalition (Milne \& Mauzy, 1999).

While the Mahathir years have been characterised as a period of high levels of growth and development, it also brought unprecedented levels of patronage politics with it. A new class of rent-seeking Bumiputra capitalists with close ties to party leadership emerged under Mahathir's rule. Allegations of corruption and nepotism were rife. Mahathir himself was involved as his period in office paralleled his son's rise to fortune as a corporate figure who procured several high-level government contracts primarily in the oil \& gas sector (Stewart, 2003). Anwar's firing was seen in the light of a desire for cleaner government in response to Mahathir's crony capitalism. It also highlighted a clear-cut example of the elite deliberately and overtly using state power to affect political outcome. The Barisan Alternatif seized upon these perceived grievances and sought to highlight the corrupt nature of the UMNO-led government in the run-up to the elections. Even though the authorities cracked down on Anwar' Reformasi movement, the Barisan Alternatif continued an aggressive 
election campaign criticizing patronage politics and the use of state funds to bail out politically linked-businessmen under the tagline of 'KKN': the Malay acronym for corruption, collusion and nepotism (Lim, 2002). Due to the tireless campaigning by the opposition coalition and the rough treatment of Anwar by the police while he was incarcerated, there was a split in the Malay votes in the 1999 general elections. UMNO witnessed a drop in support among Malay voters and lost a total of 22 seats mainly to PAS. It also lost control of a northern Malay state, Terengganu to PAS. Despite these setbacks, the Barisan Nasional still managed to win a comfortable majority as it retained the bulk of the Chinese, Indian and Sabah and Sarawak Bumiputra votes. Soon after the election, the Barisan Alternatif was dissolved mainly due to differences between the secular DAP and Islamist PAS. With the, fragmentation of the opposition movement, the status quo was preserved and authoritarian rule was maintained by Mahathir (Lin, 2002).

Despite the Barisan Alternatif's failed election campaign, the issues it raised regarding corruption, nepotism and government wastage still simmered in the minds of many Malaysians. Sensing that these grievances could blow-up and cause problems for the ruling coalition again if he still remained in power, Mahathir knew he had to step down in order to re-establish UMNO's credibility in the wake of such a serious challenge to UMNO's legitimacy as the primary voice of the Malays. He decided to step down as Prime Minister and announced his resignation at an UMNO Congress in October 2002, much to the shock of his party members. His supporters managed to convince him to stay on until an orderly transition of leadership could take place (Wain 2009; Martinez, 2005).

The leadership transition occurred one year later in October 2003 when Mahathir stepped down after thirty two years of rule to make way for Abdullah Badawi. As Mahathir's appointed successor, Badawi initially enjoyed the same level of authority and legitimacy that his predecessor had. He represented a fresh start for an otherwise politically fatigued nation, that still had grievances relating to ' $\mathrm{KKN}^{\prime}$ and were still discontent with the political system as Anwar's reformasi movement was still not forgotten. Upon coming to power, he promised a cleaner government by improving anti-corruption initiatives and reducing government wastage (Derichs, 2004). Numerous 'mega-projects' planned during Mahathir's rule were scrapped, much to the chagrin of the former premier. At the same 
time, he introduced a concept called 'Islam Hadhari': a moderate interpretation of Islam that emphasised human capital development, a clean and transparent government and protection of women's and minority rights, to counter the fundamentalist ideology espoused by PAS. Authoritarian rule was also relaxed during his tenure (Martinez, 2005). These developments were met with strong across the board approval from both the Malays and non-Malays, and as such allowed the National Front to post huge gains in the 2004 general elections that probably would not have been possible if Mahathir were still in charge (Case, 2004). UMNO won back most of the Malay votes it lost in the previous elections and Barisan Nasional won the elections by a massive landslide, winning 198 out of the 220 parliamentary seats. The ruling coalition also managed to wrest back the state of Terengganu from PAS and came close to unseating the Islamist party in its stronghold state of Kelantan (Martinez, 2005)

The first few years of Malaysia under Badawi's premiership could be described as a 'lull period' for authoritarianism in the country. It was during these early years of the Badawi period that the hard-line rule practiced by Mahathir was relaxed. High-handed police crackdown of opposition politicians and human rights activists were less prevalent. A few months after the 2004 elections, Anwar was acquitted from his sodomy charges by the Federal Court and was subsequently released from prison as he had already served time for his corruption charge. This period of latent authoritarianism did not last however. By the mid-point of his first term, Badawi was increasingly seen as an incapable leader who did not deliver what he promised (Lee, 2008). After initially promising moves to combat corruption by arresting and charging Mahathir-era cronies, the anti-graft initiatives became less and less prominent. There was a perceived lack of progress in the fight against corruption, and in fact cases of cronyism were alleged to have increased under his rule. The sudden rise of his son-in-law within the ranks of UMNO also raised eyebrows as Badawi ran on a platform to root out corruption and nepotism from the party (Case, 2010).

The middle class became increasingly disillusioned with these developments as hopes that UMNO and the Barisan Nasional could reform themselves in response to the grievances raised during the crisis years began to look less credible. At the same time, the grievances of ethnic minorities about lack of opportunity and unfair treatment remained unresolved. 
These disillusionments translated to the blossoming of protest movements that called for political reform. All these pent-up frustrations came to bear in late 2007, when two massive street protests in downtown Kuala Lumpur: the 'Bersih' movement calling for electoral and political reform, followed shortly by a protest by an ethnic Indian rights NGO called Hindraf demanding fairer treatment in the distribution of economic resources and government aid for that community (Lee, 2008). Both protests drew tens of thousands of people to the streets of Kuala Lumpur, and the high-handed tactics used by the security forces in clamping down on the protesters caused many Malaysians to grow uneasy (Subramaniam, 2011; Wong et.al, 2010). In light of these events, the opposition movement was also galvanised with the return of Anwar Ibrahim to national politics and the defunct Barisan Alternatif coalition was revived and given a new name: Pakatan Rakyat or the People's Pact. The protests and the government's reaction towards it was a significant element in the swing of public support towards the opposition witnessed in the 2008 general elections (Case, 2010).

\section{Elections and its aftermath}

The 2008 General Elections or GE 12 was a watershed event that significantly altered the political landscape of Malaysia. Since 1969 , no single event has had such an impact on the political direction of the country. Following the events of 2007 and voter disillusionment over Badawi's leadership, for the first time since 1969, the National Front coalition failed to gain its customary two-thirds majority in Parliament. The middle class voted for the opposition largely in protest about the ruling government's half-hearted response concerning the issues of 'KKN' and authoritarianism. Even though Badawi looked like he would reverse this course initially, it eventually became apparent that UMNO would not reform itself at that point (Lee, 2008). Besides this, the opposition movement also became better at working out a broadly appealing common agenda that captured the interest of the middle class.

In an unprecedented electoral result, the control four state legislatures changed hands from the National Front to the newly formed opposition Pakatan Rakyat coalition, in addition to the opposition coalition retaining control of the Kelantan state legislature through PAS. That meant that five out of the thirteen states in Malaysia were now under the administration 
of the federal opposition. What made this electoral event even more significant was that it was a dramatic change from just five years ago, when the Barisan Nasional won a resounding victory under Badawi's leadership. This shift in voting trend reflected the increasing maturity of Malaysian voters, especially the middle class who are growing weary of the dominance of race-based political discourse and unbridled corruption (Lim, Gomes \& Rahman, 2009, p. 98). The middle class was increasingly seeing through UMNO's use of the race card as a political tool to avoid dealing with legitimate grievances raised by the opposition. Another important take-away from this election was the emergence of the Malaysian middle class as a political force. The urban middle class form a significant bulk of the voting population and less inclined to look at political issues from an ethno-centric view compared to rural voters. This is quite clear when the election results are examined in more detail (Saravanamuttu, 2009). All-in-all the People' Pact won a total of 82 seats compared to the National Front's 140 seats in Parliament. Most of those 82 seats were considered to be urban areas, with the exception of the majority of PAS seats which were located in the rural northern areas of Peninsular Malaysia where it has a strong support base. The opposition coalition also managed to obtain a popular vote of 46.75 percent compared to the National Front's 50.27 percent, due to the support they obtained from urban and semiurban areas (Sin Chew Jit Poh, 2008). The fact that the two most industrialised and urbanised states in Malaysia fell to the hands of the opposition is also indicative of the vote swing of the urban middle class away from the ruling coalition (Pandian, 2010; Ufen, 2008).

Table 3.1 Parliamentary results of the 2008 general elections

\begin{tabular}{|l|l|l|l|l|l|}
\hline Party & Votes & $\begin{array}{l}\text { Percentage } \\
\text { of Votes }\end{array}$ & Seats won & $\begin{array}{l}\text { Percentage } \\
\text { of seats }\end{array}$ & $\begin{array}{l}\text { Seat } \\
\text { change }\end{array}$ \\
\hline $\begin{array}{l}\text { National } \\
\text { Front } \\
\text { (Barisan } \\
\text { Nasional) }\end{array}$ & $\mathbf{4 , 0 8 2 , 4 1 1}$ & $\mathbf{5 0 . 2 7}$ & $\mathbf{1 4 0}$ & $\mathbf{6 3 . 1}$ & $-\mathbf{5 8}$ \\
\hline UMNO & $2,381,725$ & 29.33 & 79 & 35.6 & -30 \\
\hline MCA & 840,489 & 10.35 & 15 & 6.8 & -16 \\
\hline MIC & 179,422 & 2.21 & 3 & 1.4 & -6 \\
\hline Gerakan & 184,548 & 2.27 & 2 & 0.9 & -8 \\
\hline PBB & 131,243 & 1.62 & 14 & 6.3 & +3 \\
\hline SUPP & 119,264 & 1.47 & 6 & 2.7 & - \\
\hline SPDP & 52,645 & 0.65 & 4 & 1.8 & - \\
\hline
\end{tabular}




\begin{tabular}{|l|l|l|l|l|l|}
\hline PRS & 33,410 & 0.41 & 6 & 2.7 & +6 \\
\hline UPKO & 58,856 & & & & \\
\hline PBS & 44,885 & & & & \\
\hline SAPP & 30,827 & & & & \\
\hline PBRS & & & 1 & 0.5 & - \\
\hline LDP & 8,297 & 0.1 & 1 & 0.5 & +1 \\
\hline PPP & 16,800 & 0.21 & 0 & 0 & -1 \\
\hline $\begin{array}{l}\text { Pakatan } \\
\text { Rakyat } \\
\text { (People's } \\
\text { Pact) }\end{array}$ & $\mathbf{3 , 7 9 6 , 4 6 4}$ & $\mathbf{4 6 . 7 5}$ & $\mathbf{8 2}$ & $\mathbf{3 6 . 9}$ & $\mathbf{+ 6 2}$ \\
\hline PKR & & & & & \\
\hline PAS & $1,590,080$ & 18.58 & 31 & 14.0 & +30 \\
\hline DAP & $1,140,676$ & 14.05 & 23 & 10.4 & +16 \\
\hline Independents & $\mathbf{1 , 1 1 8 , 0 2 5}$ & 13.77 & 28 & 12.6 & +16 \\
\hline Overall total & $\mathbf{7 , 9 4 4 , 2 7 4}$ & $\mathbf{1 0 0}$ & $\mathbf{2 2 2}$ & $\mathbf{1 0 0}$ & $\mathbf{+ 3}$ \\
\hline
\end{tabular}

*PBRS won its only seat uncontested on nomination day

Source: Sin Chew Jit Poh, 2008

As mentioned in chapter one of this thesis, the political landscape in Malaysia has always been based on ethnic considerations. The ruling National Front is essentially a coalition of three race-based parties and election candidates are determined based on the ethnic makeup of each constituency. This is because of the widely-held view that Malaysian voters tend to vote based along ethnic lines, hence the National Front's election strategy of putting up a Malay or Bumiputra candidate in a Malay majority constituency, a Chinese candidate in a Chinese majority constituency, and an Indian candidate in a constituency with a large Indian population (Pandian, 2010). The general election of 2008 however, has challenged this generally accepted notion ethnic-based party politics. It proved to be a watershed election in the sense that the opposition coalition which was made up of three non-race based parties managed to deny the traditional two-thirds majority the ruling coalition has continually enjoyed since Malaysia's first independent elections in 1959. Besides denying the two-thirds majority the opposition coalition managed to gain control of five states out of a total of thirteen in Malaysia federalist system. This includes the key states of Selangor and Penang, the two richest and most industrialised states in Malaysia (Ufen, 2008).

What is interesting about the Pakatan Rakyat's victory was that it ran on a platform that promised to de-emphasise the issue of race and ethnicity in its political deliberations. 
UMNO and the Barisan Nasional's key tool for maintaining power up to that point was the reliance on using ethnic-based issues that focussed on each component party looking after the interests of the ethnic group it represents i.e. UMNO for the Malays, MCA for the Chinese and MIC for the Indians. This move deliberately side-stepped the issues of corruption and political reform that were increasingly being seen as more important by the middle class. The shift away from ethnic-based issues to national ones indicated that UMNO's tried and tested methods were losing its efficacy. While PAS is an Islamic party that has a significant following from rural and conservative Malay voters, it does not espouse predominantly ethnic Malay based view like UMNO, even though there is a strong link between Islam and the Malay identity. Instead, it chooses to focus on Islamic virtues of justice, fairness and equality and a common Malaysian identity in the lead-up to the elections and this move bore fruit. It also openly welcomed support from non-Muslims. Its previously contested partnership with the DAP in the days of the Barisan Alternatif improved dramatically as all three parties chose instead to focus on their commitment to stand for a common Malaysian identity. The DAP while mainly a Chinese party, does have Bumiputra members in its fold and also subscribes to the equality among all Malaysians as a common election platform. The People's Justice Party is arguably the most multiracial out of the three coalition partners. It is a relatively new party compared to PAS and DAP, formed in 1999. All the major ethnic groups in Malaysia are well-represented in the PKR leadership, with many non-Bumiputra MPs among its ranks (Pandian, 2010). Besides the multiracial nature of the opposition coalition, the 2008 elections saw a voting trend that moved away from voting based on ethnic lines. For example, there were instances were Malay candidates from PKR and PAS were elected in favour of Chinese or Indian candidates from the ruling coalition in predominantly non-Malay constituencies as well as Non-Malay candidates from PKR and DAP defeating Malay candidates in certain constituencies with large Malay populations.

For the first time since independence, the ruling coalition's grip on power seems to have loosened. This gradual coming together of the opposition coupled with the rise of a politically aware middle class had weakened the resilience of the competitive authoritarian nature of the Malaysian state. A previously subdued civil society had also become more 
vibrant. While BN still clearly had control over the state institutions and an advantage in the electoral arena, it could not take its dominance in Malaysian politics for granted anymore. In the aftermath of the disastrous election result, UMNO went into damage control mode. Unhappy with Badawi's performance, there were internal pressures for Badawi to resign from his position as party president and by extension the Prime Ministership. Mahathir in particular was vocal in calling for his resignation. Even though he was officially retired from politics, he still had a great deal of influence within UMNO. Badawi was eventually forced to step down from power. He was replaced by his deputy, Najib Razak, who is the son of Tun Razak, the $2^{\text {nd }}$ Prime Minister of Malaysia (Saravanamuttu, 2008).

Understanding that demands for democratic change have already begun to take root amongst the population, Najib promised to carry out reforms to the political process (Abott, 2009). He embarked on a liberalisation program that included a raft of new initiatives. The New Economic Model was introduced as a replacement to the NEP, moving towards a more needs based rather than race-based approach to wealth distribution. The Internal Security Act was gradually done away with in 2011. Public rallies and street protests were also gradually being accepted and tolerated by security officials. He also sought to reconcile ethnic tensions with his '1Malaysia' concept that promoted a common Malaysian identity, which in essence was very similar to what the Pakatan Rakyat vision was. Despite these reforms, the view of urban population remained unchanged, especially in the opposition controlled states (Brown, 2013). Electoral reforms were yet to take place. This prompted a galvanising of opposition and civil society forces culminating in futher 'Bersih' rallies in 2011 and 2012. Bersih simple means clean in Malay. These rallies attracted even more people than the previous protests and the subsequent harsh treatment of protesters tarnished Najib's pro-reform image (Welsh, 2013). The root causes of their grievances i.e. corruption, inequality and government repression of civil liberties were still not resolved into resulting in those grievances to still remain in the lead-up to the next general elections in 2013.

\section{Elections and its aftermath}

After GE 12, the power balance was split for the first time in Peninsular Malaysia between the Barisan Nasional and Pakatan Rakyat. The 2013 general elections or GE 13 shifted 
Malaysia's political paradigm even further than the previous elections. It showed that the results of the 2008 elections were not a one-off event and that the protests votes against UMNO and the Barisan Nasional have evolved into votes of confidence for an opposition movement that is perceived more and more to be a credible alternative to the ruling coalition. For the first time in the nation's history the Barisan Nasional coalition failed to win the popular vote. Pakatan Rakyat captured 51\% of the popular vote (New Straits Times, 2013). The Pakatan Rakyat coalition consolidated its victories from 2008 by winning a further 7 seats, bringing its total seat count to 89. The DAP emerged as the biggest opposition party in parliament with 31 seats. While the opposition coalition managed a better performance, individually PAS and PKR actually lost a few seats to UMNO due to the latter's successful utilisation of the 'race card'; warning conservative Malay voters that a Pakatan Rakyat victory in the polls would result in the political primacy of the Malays to be extinguished (Khoo, 2013). Besides losing those seats, the opposition coalition also lost control of two of the five states it captured in 2008. It did however strengthen its position in the three states that it did control, winning a two-thirds majority in the state legislatures of those states, which are: the PAS stronghold of Kelantan and the two most industrialised states in Malaysia, Penang and Selangor (Ostwald, 2013). Overall the elections saw a greater shift of non-Malay support towards the opposition while some Malay support was regained by the ruling coalition.

Even though they won the popular vote, due to the configuration of the electoral system saw UMNO and Barisan Nasional retain its majority in parliament by winning a vast majority of the rural seats. Gerrymandering had allowed the ruling coalition to win $60 \%$ of the seats despite only winning $47 \%$ of the popular vote. Besides this, there were widespread allegations of electoral irregularities during GE 13, in particular the issue of phantom and foreign voters raised by Bersih and the opposition. Pakatan Rakyat initially disputed the results of the elections as it claimed the electoral process was marred by irregularities. Allegations of foreigners voting during the election were brought up by the opposition. Numerous videos were posted on Facebook purportedly showing Bangladeshi and Indonesian migrant workers lining up to vote at polling centres. There were also unverified claims of 'black outs' or power outages occurring during the vote counting process in certain 
seats where Pakatan Rakyat candidates suffered narrow defeats (Khoo, 2013). Social media carried these unconfirmed reports and the news spread like wildfire across the internet. With millions of Malaysians convinced that the election was rigged, Anwar and the other Pakatan leaders led nationwide rallies were held denouncing the election results and these events were attended by hundreds of thousands of people (Freedom House; Oswald, 2013). Najib decided against cracking down by allowing the protests to go ahead and only a light police presence was maintained throughout most of these rallies.

Table 3.2 Parliamentary results of the $\mathbf{2 0 1 3}$ general elections

\begin{tabular}{|l|l|l|l|l|l|}
\hline Party & Votes & \% of vote & Seats & \% of seats & Seat change \\
\hline $\begin{array}{l}\text { Barisan } \\
\text { Nasional }\end{array}$ & $\mathbf{5 , 2 3 7 , 9 8 6}$ & $\mathbf{4 7 . 3 8}$ & $\mathbf{1 3 3}$ & $\mathbf{5 9 . 9 1}$ & $-\mathbf{7}^{*}$ \\
\hline UMNO & $3,252,484$ & 29.45 & 88 & 39.64 & +9 \\
\hline PBB & 232,390 & 2.10 & 14 & 6.31 & - \\
\hline MCA & 867,851 & 7.86 & 7 & 3.15 & -8 \\
\hline PRS & 59,540 & 0.54 & 6 & 2.70 & - \\
\hline MIC & 286,629 & 2.59 & 4 & 1.80 & +1 \\
\hline PBS & 74,959 & 0.68 & 4 & 1.80 & +1 \\
\hline SPDP & 55,505 & 0.50 & 5 & 1.80 & - \\
\hline UPKO & 53,584 & 0.48 & 3 & 1.35 & -1 \\
\hline Gerakan & 191,019 & 1.73 & 1 & 0.45 & -1 \\
\hline SUPP & 133,603 & 1.21 & 1 & 0.45 & -5 \\
\hline PBRS & 9,467 & 0.08 & 1 & 0.45 & - \\
\hline LDP & 13,138 & 0.12 & 0 & 0 & -1 \\
\hline PPP & 7,530 & 0.07 & 0 & 0 & - \\
\hline $\begin{array}{l}\text { Pakatan } \\
\text { Rakyat }\end{array}$ & $\mathbf{5 , 6 2 4 , 0 1 1}$ & $\mathbf{5 0 . 8 7}$ & $\mathbf{8 9}$ & $\mathbf{4 0 . 0 9}$ & $+\mathbf{7}$ \\
\hline DAP & $1,736,601$ & 15.71 & 38 & 17.12 & +10 \\
\hline PKR & $2,254,211$ & 20.39 & 30 & 13.51 & -1 \\
\hline PAS & $1,633,199$ & 14.77 & 21 & 9.46 & -2 \\
\hline Independents & 192,890 & 1.75 & 0 & 0 & 0 \\
\hline $\begin{array}{l}\text { Invalid/blank } \\
\text { votes }\end{array}$ & 173,661 & - & - & - & - \\
\hline Total & $\mathbf{1 1 , 2 2 8 , 5 4 8}$ & $\mathbf{1 0 0}$ & $\mathbf{2 2 2}$ & $\mathbf{1 0 0}$ & - \\
\hline $\begin{array}{l}\text { Registered } \\
\text { voters/turnout }\end{array}$ & $13,268,002$ & 84.63 & - & - & - \\
\hline & & & & & \\
\hline
\end{tabular}

* Net seat change of component parties is -5 . Sabah Progressive Party left the National Front after the 2008 election, which accounted for 2 more seats lost.

Source: New Straits Times, 2013 
Another observation made following the results of GE 13 was that the rural-urban divide, which was present in the previous 2008 elections, became more deep-seated. Anwar's Pakatan coalition won in every major urban centre in the country, including in Sabah and Sarawak where it made significant inroads. UMNO and Barisan Nasional in contrast won the vast majority of the rural seats in the country. As mentioned previously, due to the redrawing of electoral boundaries over a period of three decades, the number of rural seats in the country is much higher than the urban seats even though the majority of the country's population lives in the urban areas. As such, winning the rural vote allowed the ruling coalition to stay in power. The extensive social media campaign initiated by the opposition in the lead up to the elections had minimal effect in the rural areas due to the lack of internet penetration (Jo-Ann, 2013). At the same time, government hand-outs and development programmes for farmers and low-income households who are primarily concentrated in the rural areas, together with the reliance on news from the heavily progovernment mainstream media ensured victory for UMNO (Case, 2010). This approach did not work for its coalition partners the MCA and MIC did not do as well because most of their seats are located in urban and semi-urban areas, where the bulk of the non-Malay population is concentrated at. Due to the continuance of the vote swing of non-Malay votes away from the ruling coalition witnessed in 2008, the 2013 election results further extended the unequal power relation between UMNO and the non-Malay component parties in the Barisan Nasional.

Following the return of some of the Malay vote to UMNO and the migration of the nonMalay vote to the opposition coalition, in the aftermath of the elections race relations became tenser. One of the leading Malay dailies, owned by UMNO, put out a front page headline questioning the intentions of the non-Malay and especially the Chinese voters. They were criticised for not being loyal to the government and wanting to remove the Malays from a position of Malay dominance. They proceeded to substantiate their claims by pointing out the fact that the DAP whose membership and leadership were primarily of Chinese origin were now the second largest party in parliament. The Prime Minister himself claimed that the ruling coalition lost because of a 'Chinese Tsunami' (Khoo, 2013). This is despite the fact that a closer analysis of the election results showed that the vote swing 
towards the opposition was multiracial and largely consisted of urban and middle class voters, of whom the Chinese form a significant bloc (Welsh, 2013). What was conveniently forgotten by many UMNO leaders was that a great number of Malays were also part of this urban and middle class and the movement of votes suggested a political backlash from this section of the demographic.

The continued use of the race card by UMNO after the elections was in conflict with Najib's policy of inclusiveness. As Najib's positioned was weakened within UMNO as he had failed to regain the two thirds majority and win back the state of Selangor as he promised he would before the elections, the more conservative elements within UMNO began to adopt a more pro-Malay stance instead of trying to reach out to the non-Malays in order to win back their votes. This racial posturing set the scene for the deepening of ethnic tensions and the use of UMNO's divide and rule policy in order to maintain power. It chose to focus its efforts on the maintaining and increasing its support from the majority Malay demographic at the expense of losing even further support from the Chinese and Indians (Welsh, 2013). The emergence of an ultra-Malay NGO called Perkasa is an example of the race baiting tactic used by UMNO. Although Perkasa had no official links to UMNO, it had close ties with many of its leaders and in fact had Mahathir as its patron (Case, 2010).

The results of the elections showed a continuing shift in momentum for the opposition's brand of inclusive politics. Even though the Barisan Nasional managed to retain its majority in parliament through electoral arrangements that greatly benefitted incumbent rule, it suffered a serious blow to its credibility and legitimacy. The gradual coming together of civil society elements such as Bersih and a more energised and united opposition coalition in the form of Pakatan Rakyat tested the resilience of the single party dominant system in the country (Saravanamuttu, 2008). The role of the middle class and the youth vote as key drivers for democratic change was also highlighted in these elections. These developments are a sign that the old tools used by UMNO to maintain state power are losing their efficacy and in fact becoming counterproductive (Welsh, 2013). However, UMNO and Barisan Nasional's use of cash hand-outs and old-style racial politics was enough for it to retain support among the primarily Malay rural population as well the rural Bumiputra population in Sabah and Sarawak (Khoo, 2013). It remains to be seen whether this approach can still 
ensure victory for the ruling coalition in the next polls. Going forward, the possibility of democratic transition in Malaysia has become much more real following GE 12 and GE 13.

\section{Factors promoting the deepening of democracy in Malaysia and prospects for change}

Based on the results of the 2008 and 2013 general elections, it has become increasingly clear that Malaysia is moving closer towards a two-party or two-coalition system. It can be argued that the gradual erosion of government effectiveness in adapting to changing social conditions coupled with the gradual coming together of civil society and opposition has led to the current situation of a much more competitive political landscape in Malaysia. The resurgence of the opposition movement in the country is an important factor in the deepening of democracy in the country. The previously fragmented opposition which was hampered by government crackdowns, ideological differences and a lack of common leadership has now formed a stronger bond. The loose coalition of the Barisan Alternatif has evolved into a more integrated opposition movement in the form of Pakatan Rakyat. The return of Anwar Ibrahim to the centre-stage of Malaysian politics has undoubtedly energised the opposition. The ideological differences between PAS and DAP was partly resolved with Anwar's leadership through PKR. The opposition has campaigned with a common election platform and is gradually moving away from its previous role as simply a critic of government policies to one which gives voters an alternative vision for the future of the country (Welsh, 2013; Case, 2013). If the opposition Pakatan Rakyat coalition manages to sort out its remaining differences and become a cohesive political like Barisan Nasional whose candidates contest under a common banner, there is a strong chance that a change of government can take place in the future.

In the case of Malaysia, the rise of the internet and social media is also an element that has aided the democratisation process. With mainstream media outlets controlled either directly or indirectly by the $\mathrm{BN}$, the online space became an increasingly more prominent as a tool for the dissemination of information for the opposition movement (Brown, 2013). With higher internet penetration rates and the greater use of social media, the opposition took advantage of this by conducting an extensive online campaign (Ufen, 2008). Indeed, Pakatan Rakyat's online campaign greatly outpaced Barisan Nasional's. With the 
opposition's use of online campaigning and the influx of online news which were exempt from government censorship laws, the advantage of reach and coverage previously enjoyed by the Barisan Nasional has been largely negated. The internet was kept uncensored due to Mahathir's policy of limited government regulation of the internet in efforts to make Malaysia an ICT hub under the Multimedia Super Corridor initiative (Wain, 2009). While the BN's advantage of reach and coverage were still present in the rural areas, that advantage did not extend to the urban areas where internet penetration and social media use was high.

At the same time, the increased political awareness of the middle class has also led to a shift in the political paradigm. A previously apathetic middle class who were happy to surrender political liberty in order to partake in the national development process have become more critical of the old-style patronage politics which continues to be practiced by leaders in UMNO and its Barisan Nasional component members. The economic position enjoyed by the middle class means that they no longer have to rely on government help anymore. This freedom from state influence has led to many members of the middle class to become more vocal about their aspirations for the country. While cost of living issues remain important, the middle class have increasingly focussed their attention to issues relating to transparency, clean government and the practice of race-based politics (Welsh, 2013). The blossoming of civil society movements ties in to the rise in political activism by the middle class as most of these movements rely on the support and momentum generated from this particular section of the demographic. Due to this, even UMNO and the Barisan Nasional are trying to shed their conservative image and become more progressive, in-line with new voter expectations.

Besides the rise of the middle class, another element that favours democratisation that is rarely mentioned is the increase in the population of young people relative to the rest of the country. Malaysia is currently going through a 'youth bulge' in the sense that the population of young people in the country is rising rapidly in relation to the rest of the population. Based on current projections, it is expected that by the time of the next elections, more than half of all voters would be under the age of 35 . Historically, younger voters have tended to vote for parties that run on a platform for change, and Pakatan 
Rakyat has so far been able to 'corner' most of the votes from this younger demographic. Issues of racial politics and old style development politics does not resonate with the younger voters as well (Khoo, 2013). In this regard, Anwar Ibrahim remains a popular figure among the Malay youth because of his pro-reform ideals. Going forward, the youth vote will be a game changer in the next few elections.

The ruling coalition's control of key state institutions like the police force, the civil service and the judiciary will continue to hamper the development of true democracy in the country. Control over the civil service and the federal government as well as the Election Commission have ensured that the electoral map is heavily in its favour. Despite winning the majority of the votes, Pakatan made only marginal improvements in its overall seat number in parliament. Barisan Nasional's control of the electoral system means that they still hold the incumbent advantage for the foreseeable future. The unequal apportionment of votes among the various constituencies through gerrymandering has ensured that UMNO and its Barisan Nasional allies will continue to win in the majority of the rural seats, unless the opposition makes significant inroads in those areas in time for the next general elections scheduled to occur somewhere during 2018. Since this is highly unlikely to happen due to the opposition coalition lacking the resources needed to challenge UMNO in its 'home ground', the advantage in the electoral arena enjoyed by the ruling coalition will continue to make the difference (Khoo, 2013). Despite this however, it is also highly unlikely that there will be a reversal of trends and the opposition will continue to dominate in urban areas and maintain strong support bases in the richer states. While the democratisation process in Malaysia is far from over, the necessary 'tipping point' in order for strong state democratisation to be complete is probably another two elections away at the very least.

Also, it could be argued that ethnic fragmentation in the country has become more significant now. This could present a significant barrier towards a smooth democratic transition in the country. The results of GE 12 and 13 have highlighted the shift in support from the Barisan Nasional to the Pakatan Rakyat coalition among the non-Malay communities. The majority of the non-Malay, especially Chinese support is now with the opposition (Ostwald, 2013). At the same time, the last election in 2013 has seen some of the Malay votes lost in the 2008 elections return back to the fold of the ruling coalition. 
Malay support is now marginally higher for UMNO and BN than it is for Pakatan Rakyat. Capitalising on the increase in Malay support for the UMNO-led coalition a leading UMNO owned Malay daily featured a headline criticizing the Chinese community for BN's poorer performance in the elections. Numerous incidents of race-baiting following GE 13 by the more ultra-Malay elements within UMNO and the newly formed Malay rights NGOs have only exacerbated ethnic tensions. UMNO's fall back to its role as a defender of Malay rights rather than a party that leads the ruling government has made the ethnic divide all the more apparent. The playing up of the fear of the 'other' by UMNO politicians has led to deterioration of ethnic relations. Najib's silence on the matter only means that he either lacks the political will to act on party members who are knowingly going against the '1Malaysia' policy of inclusiveness or that he tacitly approves of this method as long as it means UMNO can continue to retain power (Khoo, 2013). This could end up as a serious impediment to democracy if the impression of national politics being a question of Malays vs. non-Malays is ingrained in the minds of the rural Malay population who are still loyal to UMNO. For these reasons, the factors that are going in favour for the opposition may not be enough to see it through an electoral victory in the next elections (Welsh, 2013).

From the results of the 2008 and 2013 general elections, it is clear that the resiliency of semi-democracy or competitive authoritarianism in Malaysia has so far rested upon the structural and institutional arrangements that have embedded incumbent rule. The ability of the incumbent party to manipulate the electoral process through various methods such as gerrymandering and restricted media access to opposition politicians has allowed it to remain in power. Besides that, the ability of the ruling coalition and UMNO in particular to use Malay supremacy agenda in order to remain in power will also be an impediment to the development of democracy (Welsh, 2013; Ostwald, 2013). At the same time, a better informed citizenry and a much more vocal middle class and youth population has irreversibly changed the political landscape in Malaysia (Saravanamuttu, 2009; Brown, 2013). The ruling BN coalition will find it increasingly hard to employ some the same tactics it used before in order to woo voters. These tactics may however be enough to ensure victory in the next elections as the rural population will continue to vote for the ruling coalition as long as its development needs are being provided by them. However, the 
'tipping point' for political change might be reached in time for the subsequent general election, when the opposition would have had enough time to make stronger inroads into rural areas and when there is an even bigger increase in young voters that form a significant voting base for Pakatan Rakyat.

\section{B: Singapore}

\section{Singapore under Goh Chok Tong}

When Lee Kuan Yew stepped down from power after three decades of rule, he was replaced by his appointed successor, Goh Chok Tong in 1990. Lee remained in government with an influential position as Senior Minister. Goh Chok was Prime Minister from 1990 to 2004. Similar to the case of the leadership transition in Malaysia, Goh promised a more open and consultative style of leadership compared to his predecessor. It was under Goh's term as Prime Minister that the Group Representation Constituency or GRC system was adopted. The Non-Constituency MP system was also expanded upon during his time in office. The NCMP was original conceived in 1984 as a way to guarantee opposition representation in parliament. Under this system, opposition candidates receiving the highest number of votes without being elected into parliament would be offered NCMP seats (Hill \& Lian, 1995). The Parliamentary Elections Act provides for a minimum of nine NCMPs to be offered seats in parliament. NCMPs have the same privileges as the other MPs but cannot vote on issues relating to the amendment of the Constitution, any motion of no-confidence in the government and any motion pertaining to the amendment of a money or supply bill (Vasil, 2000). In addition to the GRC and the NCMP, the Nominated Member of Parliament (NMP) provision was also introduced. The NMP system provided for individuals who were not affiliated to any political party to have a seat in parliament. This was done to encourage more independent voices to be heard in parliament. These individuals would normally be from the professional, academic or civil society communities. Like NCMPs, NMPs could not vote on issues relating to constitutional amendments, motions of no confidence and supply and money bills (Singh, 2006). 
Despite these changes to the electoral system, during that time, the status quo was largely maintained and the PAP won comfortable majorities in elections just like it had under the leadership of Lee. Goh led the PAP to strong showings in the polls, winning $61 \%, 65 \%$ and 75\% of the popular vote for the 1991, 1997 and 2001 elections respectively (Singh, 2006). The tried and tested tactic of limiting access to the media and restricting public gatherings was continued. Besides that, there were criticisms of the NMP and GRC system. The NMP system was criticised by academics that it reinforced PAP's elitist and technocratic view of politics, as most of the NMPs elected were professionals and members of the upper-middle class elite. The GRC system meanwhile was argued to have entrenched PAP dominance because it made it much more difficult for opposition parties to compete in the elections as it had to devote much more of its resources and manpower in order to contest in a GRC (Mutalib, 2002). Despite all those criticisms, the vast majority of the general population continued to support the PAP because of its sound economic management policies. Singapore weathered the financial crisis of 1997 much better than its counterpart across the causeway, Malaysia. The Singaporean economy only suffered a short recession and the country's financial authorities managed to keep a full-blown crisis from developing. This enhanced the image of the PAP and Goh as capable leaders in steering the country in a time of crisis when regional neighbours like Thailand and Indonesia descended into turmoil. This led to the PAP achieving a big win in the 2001 polls, where it won $75 \%$ of the vote and 82 out of a possible 84 electoral seats (Singh, 2006).

\section{Singapore under Lee Hsien Loong}

Goh stepped down as Prime Minister in 2004, citing that he has fulfilled his duties in bringing Singapore out of the financial crisis and developing Singapore's economy further and that it was time for someone else to take the helm. A transition process had already been developed as his deputy, Lee Kuan Yew's son Lee Hsien Loong had been groomed as his successor since the day Goh took office as Prime Minister. When Lee Hsien Loong took office, Singapore was entering a new phase in its development stage. It was already a highincome nation with one of the highest per capita incomes in the world. Already prosperous, the demands of the population have changed. Issues regarding quality of life and greater space for freedom were more prominent (Barr, 2012). This period also marked the time 
when the generation of Singaporeans who did not go through the same historical experience as their parents became were a significant part of the demographic. This generation was not brought up under the rule of Lee Kuan Yew and as such do not have the historical 'baggage' that accompanied it. They did not view the PAP the same way as their parents did (Verweij \& Pelizzo, 2009).

Understanding this, the younger Lee already had the idea to cede some control of the state in the private and people sectors. For instance he introduced the policy of the 'Five Day Work Week" that would remove Saturday as a half-working day. Under Lee's term, the use of the Speakers Corner was also encouraged to a greater extent. The Speakers Corner is an area located within one of the main parks in the city centre and was designated as a 'free speech area' by the previous Goh government in 2000 as a place where Singaporeans could hold exhibitions, performances and speak freely on any issue. Even though it was technically not 'free speech' as citizens had to register their intentions to speak or perform there on a government website beforehand (Mutalib, 2002). Lee wanted the PAP to be responsive to the needs of the younger generation of Singaporean voters by relaxing some restrictions of the Singapore nanny-state. Indeed, these initiatives helped the PAP to continue its electoral dominance in the 2006 general elections, where it maintained the same results as the previous elections, winning 82 out of the 84 seats it contested (Singapore Elections, n.d.b). To prove that he was serious about political reforms even after a strong electoral showing, he brought his reform agenda even further when in May 2010, the PAP under Lee's leadership initiated several changes to the electoral system. There was a reduction in the number of Group Representation Constituencies (GRCs), to allow opposition parties to participate in the election more effectively. Besides that he also increased the number of Non-constituency Members of Parliament (NCMPs) to a maximum of nine and the number of Nominated Members of Parliament (NMPs) to nine as well (Barr, 2012). Also part of the reforms package was the legalization of internet campaigning, thereby allowing the opposition to have a platform to promote its policies and its election manifesto (O'Callaghan, 2013). These reforms were met with general approval from the public, and many thought it was a step in the right direction for Singaporean politics. 
Despite all these reforms and initiatives however, there were still unresolved grievances among Singapore's middle class. The PAP's policy of focussing on economic development and maintaining Singapore's high growth rates was causing some disillusionment among the people. The aggressive pursuit of economic development and foreign investment into Singapore brought in a large number of migrants into country. A significant number of these migrants came in through the 'Foreign Talent' program under which skilled migrants from various other countries in Asia were allowed to work in Singapore and eventually apply for residency. This altered the demographics of the country. The presence of foreigners in the country was increasingly being felt by the Singapore's resident population (Ortmann, 2011). Singaporeans, especially from the lower middle and middle income group, felt that the presence of foreigners was squeezing them out from the job market. At the same time, issues relating to inequality were also becoming more apparent. Despite having one of the highest per capita incomes in the world at approximately 52000 dollars per year, almost 1 in 10 Singaporean households were earning an average monthly income of 1,323 dollars (Singapore Statistics, 2013). The citizens at the lower rung of the economy had to eke out a living as Singapore does not practice a welfare state policy. All these grievances were capitalised on and picked-up by the various opposition parties and integrated these issues into their election campaign for the 2011 general election.

\section{1 general elections}

The 2011 general elections in Singapore presented an interesting development in an otherwise predictable election outcome for the PAP. The opposition posted its biggest ever showing in the country's electoral history. The elections also marked the highest number of seats contested by the opposition yet. In previous elections, many GRC seats were left uncontested by opposition parties, allowing the PAP to obtain walkovers. This time however, 82 out of a total 87 seats were contested by the opposition. These elections were also considered a 'watershed' political event in that it also marked the first time that an opposition party won a GRC (Ortmann, 2011). The Worker's Party, a centre-left party under the leadership of Low Thia Khiang, managed to unseat the incumbent PAP team at the Aljunied GRC which included a senior cabinet member, foreign minister George Yeo. This was a significant achievement for the opposition and was a milestone of sorts in 
Singaporean politics. The opposition improved its tally of seats won from one in the 2006 elections to six. The 2011 elections also marked the beginning of a credible opposition movement in the form of the Worker's Party as it won all six of those constituency seats. Conversely, the PAP managed its worst electoral performance since 1963 . While the PAP did secure a comfortable victory by winning 81 out of 87 seats, it only managed to win $60 \%$ of the total vote, its lowest share of the vote since 1963. In any other democracy, $60 \%$ of the vote would be an excellent achievement for the winning party. Since Singapore is not a full democracy however, the $60 \%$ vote share it managed despite the massive advantage it had over all the other parties caused them to suffer a significant dent to their authority (Singapore Elections, n.d.c).

Table 3.3 Parliamentary results of the 2011 Singapore general elections

\begin{tabular}{|c|c|c|c|c|c|c|c|}
\hline Party & $\begin{array}{l}\text { Contested } \\
\text { seats }\end{array}$ & $\begin{array}{l}\text { Seats } \\
\text { won }\end{array}$ & $\begin{array}{l}\text { Popular } \\
\text { vote }\end{array}$ & $\begin{array}{l}\% \text { of } \\
\text { valid } \\
\text { votes }\end{array}$ & $+/-$ & $\begin{array}{l}\% \text { of valid } \\
\text { votes in } \\
\text { contested } \\
\text { wards }\end{array}$ & $+/-$ \\
\hline PAP & 87 & $81^{\wedge}$ & $1,212,154$ & 60.14 & -6.46 & 60.14 & -6.46 \\
\hline $\begin{array}{l}\text { Worker's } \\
\text { Party }\end{array}$ & 23 & 6 & 258,510 & 12.83 & -3.51 & 46.58 & +8.15 \\
\hline $\begin{array}{l}\text { National } \\
\text { Solidarity } \\
\text { Party }\end{array}$ & 24 & 0 & 242,682 & 12.04 & -0.95 & $39.25 *$ & +6.37 \\
\hline $\begin{array}{l}\text { Singapore } \\
\text { Democratic } \\
\text { Party }\end{array}$ & 11 & 0 & 97,369 & 4.83 & +0.76 & 36.76 & +13.53 \\
\hline
\end{tabular}




\begin{tabular}{|l|l|l|l|l|l|l|l|}
\hline $\begin{array}{l}\text { Reform } \\
\text { Party }\end{array}$ & 11 & 0 & 86,294 & 4.28 & New & 31.78 & New \\
\hline $\begin{array}{l}\text { Singapore } \\
\text { People's } \\
\text { Party }\end{array}$ & 7 & 0 & 62,639 & 3.11 & -9.88 & $41.42^{*}$ & +8.90 \\
\hline $\begin{array}{l}\text { Singapore } \\
\text { Democratic } \\
\text { Alliance }\end{array}$ & 7 & 0 & 55,988 & 2.78 & -10.21 & 30.06 & -2.46 \\
\hline $\begin{array}{l}\text { Total } \\
\text { Voting } \\
\text { electorate }\end{array}$ & $\mathbf{8 7}$ & - & $\mathbf{2 , 0 1 5 , 6 3 6}$ & $\mathbf{8 5 . 6 3}$ & - & & \\
\hline
\end{tabular}

^includes uncontested seats

* Formerly a constituent party of Singapore Democratic Alliance. Swings reflected are from the SDA's 2006 vote share.

Source: Singapore Elections, n.d.c

Overall, the opposition managed to win approximately $40 \%$ of the combined vote. Even though the opposition vote was split between numerous parties, this was an important achievement as it was the first time since the closely fought elections of 1963 that the combined opposition vote share broke the $40 \%$ mark. It also marked a $7 \%$ increase in votes from the previous election year. Despite this however, none of the other five opposition parties won seats in the constituencies they contested in. The Singapore People's Party even lost the Potong Pasir SMC it won in 2006 to the PAP, albeit by a razor-thin 114 votes (Singapore Elections, n.d.c). Based on the results, had some of the opposition parties pooled their resources and formed a coalition, they could have mounted an even stronger 
challenge to the PAP at the polls. In relation to that, the vote share of the PAP dropped for the second time. It lost $8.7 \%$ of the vote in 2006 and a further 6.5\% in 2011 (Singapore Elections, n.d.c). This consecutive drop in support raised some alarm bells among the PAP leadership. The PAP had to adapt to be more responsive to citizen demands or risk an even further dent to their moral authority (Barr, 2012). The elections proved that the nanny state approach and the tried and tested tactics of limiting political expression that have ensured support for the PAP will not work as well as it did before (Tan, 2012). While the PAP still holds a tremendous a tremendous advantage over any opposition party and still dominates the political scene, it could not expect to so easily achieve a massive electoral victory anymore.

\section{2 \& 2013 by- elections}

Two by-elections have been held ever since the concluding of the 2011 general elections. The first was the Hougang SMC by-election in May 2012. A by-election was called for the constituency when Yaw Shin Leong, the incumbent was expelled from the Worker's Party due to several indiscretions in his private life. Under Singapore's Constitutional laws, the seat of an MP will be declared vacant if that MP has been expelled from the party under whose banner he or she stood for in the election (Lee, 2012). As the Hougang seat was one of the few areas where the PAP would consider itself an underdog since it was an opposition stronghold, it was expected that the candidate fielded by the Worker's Party would win. The seat was held for two consecutive general elections by Worker's Party leader Low Thia Khiang even before the 'watershed' 2011 elections. Surely enough, Png Eng Huat of the Worker's Party emerged as the victor during the by-elections, winning $62 \%$ of the valid votes cast. The PAP's Desmond Choo who contested in the same seat in 2011, only managed $38 \%$ of the vote (Singapore Elections, n.d.d). This result reaffirmed that voters in the Hougang area were happy with the Worker's Party representing them. While the result was not surprising, it showed that the PAP still had a lot of work to do in order to win back support particularly in voters from the Hougang area. In contrast, the 2013 by-elections in Punggol East was a much more important contest for the PAP as it was defending the seat. 
The 2013 by-elections in the Punggol East SMC were held in January 2013 due to the resignation of the incumbent, Parliamentary Speaker Michael Palmer. Palmer resigned after revelations of him having an extramarital affair. The by-elections were an acid test for the PAP, as it was defending this seat and sought to regain public approval following its lacklustre performance in the 2011 polls. At the same time, the Workers Party was keen to capitalise on its better than expected performance in the general elections by capturing another seat that was previously held by the PAP. Seeking to win over new voters, the PAP introduced a new face as its candidate, in the form of Koh Poh Koon, a colorectal surgeon. The Worker's Party chose to field the same candidate it fielded in the 2011 elections there, Lee Li Lian. Lee had already obtained $41 \%$ of the vote in 2011, and the Worker's Party assessed that their chances of winning the seat are high this time, given the circumstances of the departure of the incumbent MP (Singapore Elections, n.d.e.). Other opposition candidates who contested were Kenneth Jeyaretnam of the Reform Party who is the son of the late opposition stalwart JB Jeyaretnam, and Desmond Lim from the Singapore Democratic Alliance (Channel News Asia, 2013).

The Worker's Party consolidated its victories in the 2011 elections when it captured the seat from the PAP. Lee won the seat with a strong majority of $54.5 \%$. The 10.8 point percentage difference in votes between her and the PAP candidate Koh was the highest margin of victory since the PAP's victory in the seat in 1984 (Adam, 2013). The scope of PAP's loss indicated that its policies did not alleviate the rising discontent among Singaporeans regarding the rise in prices, inequality and the influx of foreign workers. As the government's perceived mishandling of those issues were key campaign points for Lee and the Worker's Party. This latest poll result suggests that those issues remain as grievances for many in Singapore's middle class and the political momentum still belongs to the opposition, in particular the Worker's Party (Ganesan, 2013). It remains to be seen whether the PAP will be able to regain the support it lost from the 2011 elections and the 2012 and 2013 by-elections or lose even more support in the next general elections scheduled for 2016. 


\section{Factors promoting the deepening of democracy in Singapore and prospects for change}

The systematic side-lining of the opposition movement in Singapore from the mainstream national discourse had seriously impacted their ability to make inroads with the general populace and the ballot box. With the advent of social media in a country that already has extremely high internet penetration rates, this is slowly changing. In addition, the reforms made during Goh Chok Tong's term as Prime Minister as well as Lee Hsien Loong's first term have at least made easier for the opposition movement to organise itself (Barr 2012 ; Verweij \& Pelizzo, 2009). Those reforms facilitated the development of a stronger opposition movement. However, unlike the case of Malaysia, the opposition in Singapore is very fragmented. There is no Pakatan Rakyat equivalent in the country. In the 2011 elections for example, there were a total number of seven opposition parties contesting. In Malaysia, the vast majority of the seats were straight fights between Barisan Nasional and Pakatan Rakyat candidates. In the 2011 elections, there were many three or even four cornered fights between the PAP and the various opposition parties. The Worker's Party and the National Solidarity Party had vote shares of $12.83 \%$ and $12.04 \%$ respectively (Singapore Elections, n.d.c). If both parties had entered into a coalition of some sort, they could have maximised their vote potential. The lack of unity among opposition parties in Singapore presents an obstacle for the consolidation of democracy as a viable opposition movement is an important criteria for that to happen.

Similar to the case of Malaysia, the change in political attitudes among Singapore's middle class has also been an important factor that has improved the quality of democracy in the country. However there is a difference in the type of issues that are close to the hearts of the middle class in both countries. While issues such as corruption and government inefficiency which are important grievances for the Malaysian middle class, those same grievances do not exist in Singapore (Barr, 2012). Instead, the growing gap between the rich and poor, rising housing costs, high levels of immigration into the country are issues that have caused considerable outcry among many in Singapore's middle class (Ganesan, 2013). In relation to the increase in the cost of housing and other essentials, the enormous pay packets of government ministers (Ministers in Singapore are the highest paid in the world) is increasingly being seen in the context of the growing gap between the rich and the poor 
by many Singaporeans who are struggling with the increasing cost of living (Adam, 2013). Inequality in Singapore is relatively high for a developing country, and if this issue remains unresolved, there will definitely be a greater migration of votes among the middle and lower-middle income groups to the centre-left Worker's Party. Given the fact that the size of the middle class in proportion to the rest of the population is much larger in Singapore than it is in Malaysia, the country's middle class will be one of the most if not the most integral drivers for democratic change.

In addition to bread and butter issues, the new generation of voters who did not live under the shadow of Lee Kuan Yew's rule have different aspirations than those of their parents. Having achieved a first world level of economic prosperity, the desire greater personal freedom has increased among this section of the demographic. The reforms instituted by the PAP in relation to these demands did not result in the PAP gaining support from this section. Instead, the young voters have begun to embrace this new found freedom by taking to online media portals and adopting alternative viewpoints than that of the standard PAP viewpoint of the importance of loyalty and hierarchy in national development. The patriarchal state concept that has long been practiced by the PAP does not resonate with younger voters anymore. While many in the PAP have understood this and initiated reforms, these changes may be too slow in the eyes of many new generation voters. Going forward, it is highly likely that the PAP will continue to lose support from this voter base. However, given the fact that Singapore's population is aging unlike Malaysia's the vote swing will not be as damaging to the PAP as it will be to UMNO (Barr, 2012).

The PAP's strong influence over the electoral system and its inseparable link to the civil service and other state institutions means that it will continue to win elections even though it will probably experience a gradual loss in the share of the popular vote. At the same time, subsequent elections will probably see an increase in the number of seats won by opposition parties, most notably the Worker's Party. Other parties such as the National Solidarity Party may be able to win one or two seats with the trend of increasing support for the opposition, however unless parties such as the NSP from a coalition with the Worker's Party, the full potential of the opposition movement will not be realised (Tan, 2012). Besides that, the fact that changes to the electoral system such as the introduction 
of the NMP and the NCMP as well as the reduction in the number of GRCs has showed that the PAP is more responsive and adaptive to the demands of its citizens (Barr, 2012).

While the ruling party in neither country has fully met the growing internal pressures for a more open political system, the PAP enjoys a greater degree of legitimacy through concerted efforts to open political debate and include more voices in the decision-making process in parliament (Ortmann, 2011). Because the PAP have managed to accommodate the grievances of citizens through reforms like the NMP that seeks to fosters a more diverse range of views in the policy-making process, these institutional changes have arguably given the PAP a stronger standing compared to its counterpart across the Causeway despite its consecutive drop in the share of the popular vote (Tan, 2012). This is because the UMNOled government, while more open to criticism than before, does not have a process in place such as the one created by the PAP that allows them to accommodate alternative viewpoints into important policy decisions. Therefore, the PAP will be better prepared to withstand the democratisation pressures by adopting this more conciliatory approach. In addition to this, the slow-burning problems of inequality and immigration in Singapore as opposed to corruption and political reform in Malaysia are harder to turn into a political agenda that people can mobilise behind (Verweij \& Pelizzo, 2009; Ganesan, 2013). To put it simply, these issues alone are not enough for the opposition to persuade voters to vote for a change in government. For these reasons the PAP will continue retain its majority in parliament, albeit with reduced majorities and a reduced share of the national vote for the foreseeable future. 


\section{Conclusion}

This thesis covered the development of the competitive authoritarian state in Malaysia and Singapore and how recent changes have affected the resilience of that system using an analytical framework that focussed on the historical consolidation of state strength by the ruling party vs. the emergence of civil society and the rise in social capital among the population. It sought to address the question as to whether competitive authoritarianism and the single party dominant system would be able to withstand increasing pressures to democratise. Malaysia was used as the main reference point throughout the course of this paper, and comparisons were made between the single party dominant systems in both countries. The first chapter gave a brief description about the demographic situation in both countries and proceeded to give a concise yet detailed account of the historical development of competitive authoritarianism there. The second chapter looked at the key sources of strength that has allowed the competitive authoritarian system to flourish in both states. The third chapter then examined recent developments and changes to the political landscape in both countries. Keeping in mind the strengths of the single party dominant system in Malaysia and Singapore and the recent pressures to democratise, the prospects for democratic transition in both states was looked into.

Based on this study of the competitive authoritarian systems present in both countries, it is clear that Singapore's system is more resilient than Malaysia's. Even during the rule of Mahathir who ushered in a stable phase of authoritarian rule, there were challenges to his authority in the form of his UMNO rivals, one of whom is currently the leader of the strongest opposition movement ever witnessed in Malaysia. In contrast, factional politics were almost non-existent within the PAP and Lee led the party unhindered. While the past two elections have seen the opposition movement in Malaysia mount a serious challenge to the ruling Barisan Nasional coalition, the PAP has not had the same level of competition in the Singaporean polls. For the first time in many years, the credibility and the legitimacy of the UMNO-led government has been seriously affected. Najib is in charge of a ruling coalition that is considered to be a 'minority government' by vast swaths of the Malaysian

public, as it governs without popular mandate. As things stand presently, democratic 
transition is much more likely to happen in Malaysia because of the rise of a strong opposition movement, a politically empowered middle class and more vibrant civil society.

This paper reaches the conclusion that the democratisation process in both countries will continue to move forward, despite the institutional arrangements and other factors that work against it. Based on a combination of the existing literature and the review of the political developments that have taken place in both countries, it is clear that civil society and social capital are vital ingredients to the democratisation process in strong authoritarian states. As the opposition and civil society movements gradually come together, the prospect for democratic transition to occur is much brighter. While a change in government will not occur in both countries anytime soon, based on the reasons given throughout the course of this thesis, it is expected that Malaysia will experience a democratic transition sooner than Singapore. While there are some concerns over the state of race relations in Malaysia, on the whole the democratisation and transition process should be fairly stable. Singapore meanwhile will go through an even slower transition phase as the ruling party there is not threatened with the same level of loss in support and other legitimacy issues. From the study of the political systems in both countries, it can be said that the democratisation process in strong states does indeed take time, but the process is a lot smoother and gradual compared to democratic transitions in authoritarian states that lack strong state capacity. 


\section{Bibliography}

Abbott, J. (2009) Malaysia's transitional moment? Democratic transition theory and the problem of Malaysian exceptionalism, South East Asia Research 17(2) pp.175-200.

Abraham, C. (1997) Divide and Rule, The Roots of Race Relations in Malaysia (Kuala Lumpur:INSAN).

Acharya, A. (2003) Democratisation and the Prospects for Participatory Regionalism in Southeast Asia, Third World Quarterly 24(2) pp.375-390.

Adam, S. (29 January 2013) Singapore By-Election Loss Shows Lee Challenges: Southeast Asia, Bloomberg News. Retrieved from: http://www.bloomberg.com/news/2013-01$\underline{\text { 26/singapore-ruling-party-suffers-vote-defeat-in-setback-for-lee.html }}$

Alagappa, M. (ed.) (2001) Civil Society and Political Change in Asia (Stanford: Stanford University Press).

Ariffin, O. (2009) The Struggle for Ethnic Unity in Malaya after the Second World War pp.45-58 in Lim, T.G., Gomes, A. \& Rahman, A. Multiethnic Malaysia: Past, Present and Future (Kuala Lumpur: SIRD Press).

Barr, M. (2012) The bonsai under the banyan tree: democracy and democratization in Singapore, Democratization. DOI:10.1080/13510347.2012.706606

Brown, G. (2013) Malaysia in 2012: Promises of Reform; Promises Met? Southeast Asian Affairs Vol. 2013, pp. 153-167.

Case, W. (1993) Semi-Democracy in Malaysia: Withstanding the Pressures for Regime Change, Pacific Affairs 66(2) pp. 183-205.

Case, W. (1996) Can the "Halfway House" Stand? Semidemocracy and Elite Theory in Three Southeast Asian Countries, Comparative Politics 28(4) pp.437-464.

Case, W. (2002) Politics in Southeast Asia: Democracy or Less (London: RoutledgeCurzon) 
Case, W. (2005) Southeast Asia's Hybrid Regimes: When do voters change them? Journal of East Asian Studies 5(2) pp. 215-237.

Case, W. (2010) Transition from Single Party Dominance? New Data from Malaysia, Journal of East Asian Studies 10(1) pp. 91-126.

Case, W. (2013) Malaysia in 2012: A non election year, Asian Survey 53(1) pp. 134-141.

Chan, H.C., Seah, C.M., \& Quah, J. (1987) Government and Politics of Singapore

(Singapore: Oxford University Press).

Cheah, B.K. (2009) Race and Ethnic Relations in Colonial Malaya during the 1920s, pp.3344 in Lim, T.G., Gomes, A. \& Rahman, A. Multiethnic Malaysia: Past, Present and Future (Kuala Lumpur: SIRD Press).

Cheah, B.K. (2004) Ethnicity and Contesting Nationalisms in Malaysia. In Cheah, B.K., The Challenge of Ethnicity, Building a Nation in Malaysia (ed.) pp.40-53. (Singapore: Marshall Cavendish).

Channel News Asia (14 January, 2013) PAP fields Koh Poh Koon as its candidate for byelection. Retrieved from:

http://www.channelnewsasia.com/stories/singaporelocalnews/view/1247058/1/.html

CIA (2013) The World Factbook - Malaysia. Retrieved from:

https://www.cia.gov/library/publications/the-world-factbook/geos/my.html

CIA (2013) The World Factbook - Singapore. Retrieved from:

https://www.cia.gov/library/publications/the-world-factbook/geos/sn.html

Crouch, H. (1996) Government and Society in Malaysia (Ithaca: Cornell University Press).

Derichs, C. (2004) Political crisis and reform in Malaysia in Gomez, E. The State of

Malaysia: Ethnicity, equity and reform (ed) (London: Routledge Curzon).

Freedom House (2013) Freedom in the World - Malaysia. Retrieved from:

http://freedomhouse.org/report/freedom-world/2013/malaysia\#.U22hc mSzO0 
Freedom House (2013) Freedom in the World -Singapore. Retrieved from:

http://www.freedomhouse.org/report/freedom-world/2013/singapore\#.U22gx mSz00

Ganesan (2013) Singapore in 2012: A Year of Scandals, Attempted Political Engagement, and Socio-economic Anxieties, Southeast Asian Affairs pp.252-272.

Giddens, A. (1990) Consequences of Modernity (Palo Alto: Stanford University Press).

Ginsburg, T. (2008) Lessons for Democratic Transitions: Case Studies from Asia, Orbis: A Journal of World Affairs 52(1) pp. 91-105.

Grugel, J. (2002) Democratization: A Critical Introduction (New York: Palgrave Macmillan).

Gomez, E. (2009) Ethnicity, Equity and Politics in Multiethnic Malaysia in Lim, T.G., Gomes, A. \& Rahman, A. Multiethnic Malaysia: Past, Present and Future (Kuala Lumpur: SIRD Press).

Gomez, E. (2004) The State of Malaysia: Ethnicity, equity and reform (ed) (London: Routledge Curzon).

Haerpfer. C.W., Bernhagen, P., Inglehart, R.F. and Welzel, C. (2009) Democratization (New York: Oxford University Press).

Hill, M. and Lian, K.F. (1995) The Politics of Nation-Building and Citizenship in Singapore (Singapore: Routledge).

Housing Development Board (2013) Ethnic Integration Policy. Retrieved from: http://www.hdb.gov.sg/fi10/fi10322p.nsf/w/SellFlatEthniclntegrationPolicy EIP?OpenDoc $\underline{\text { ument }}$

Jayasuriya, K. and Rodan, G. (2007a) Beyond Hybrid Regimes: More Participation, Less Contestation in Southeast Asia, Democratization 14(5) pp. 773-794.

Jayasuriya, K. and Rodan, G. (2007b) New Trajectories for Political Regimes in Southeast Asia, Democratization 14(5) pp. 767-772. 
Jo Ann, D. (30 September, 2013) Malaysia's compromised electoral system, The Nut

Graph. Retrieved from: http://www.thenutgraph.com/malaysias-compromised-electoralsystem/

Jones, M. (2000) Creating Malaysia: Singapore Security, the Borneo Territories and the Contours of British Policy, 1961-1963, Journal of Imperial and Commonwealth History, 28(2) pp. 85-109.

Kua, K.S. (2007) May 13: Declassified Documents on the Malaysian Riots of 1969 (Kuala Lumpur: Suaram).

Khoo, B.T. (2013) $13^{\text {th }}$ General Elections in Malaysia: Issues, Outcomes and Implications, IDE-JETRO. Retrieved from:

http://www.ide.go.jp/English/Publish/Download/Report/2013/2013 malaysia.html

Lee, C. (February 22 2012) 'Yaw not appealing expulsion, Hougang seat declared vacant' The Business Times. Retrieved from:

http://businesstimes.com.sg/sub/latest/story/0,4574,478985,00.html

Lee, H.G. (2008) Malaysia in 2007: Abdullah Administration under Siege, Southeast Asian Affairs Vol 2008, pp.187-206.

Lee, J. (2002) Primary Causes of Democratization, Asian Survey 42(6) pp. 821-837.

Levitsky, S. and Way, L. (2010) Competitive Authoritarianism, Hybrid Regimes after the Cold War (New York: Cambridge University Press).

Lipset, S.M. (1959) Some Social Requisites of Democracy: Economic Development and Political Legitimacy, American Political Science Review 53(1) pp.69-105.

Lim, H.H. (2002) Electoral politics in Malaysia: 'Managing' Elections in a Plural Society in Electoral politics in South and Southeast Asia pp.106-148.

Lin, J.Y. (2002) A Structural Analysis of the 1999 Malaysian General Election: Changing Voting Preference of Ethnic Chinese and Malay Groups and Party, Taipei: Tamkang 
Journal of International Affairs 6(3). Retrieved from:

http://www.brookings.edu/fp/cnaps/papers/lin20021219.pdf

Linz, J.J. and Stepan, A. (1996) Toward consolidated democracies, Journal of Democracy 7(2) pp.14-33.

MacIntyre, A. (2003) The Power of Institutions: Political Architecture and Governance (Ithaca, New York: Cornell University Press).

Martinez, P. (2005) Malaysia in 2004: Abdullah Badawi Defines his leaderhip, Southeast Asian Affairs Vol. 2005, pp. 189-210.

Malaysian Statistics Department (2010) Retrieved from:

http://statistics.gov.my/portal/index.php?option=com content\&view=article\&id=352\%3A population-and-demography\&catid=42\%2F\&Itemid=91\&lang=bm\#c14

Mauzy, D. and Barter, S. (2008) Learning to Lose? Not if UMNO Can Help It in Wong, J. and Friedman, E. Political Transitions in Dominant Party Systems: Learning to Lose (eds.) (New York: Routledge).

Milne, R. and Mauzy, D. (2002) Singapore politics under the People's Action Party (London: Routledge).

Milne, R. and Mauzy, D. (1999) Malaysian Politics under Mahathir (London: Routledge).

Means, G.P. (1996) Soft Authoritarianism in Malaysia and Singapore, Journal of Democracy 7(4) pp. 103-117.

Mutalib, H. (2000) Illiberal democracy and the future of opposition in Singapore, Third World Quarterly 21(2) pp. 313-342.

Mutalib, H. (2002) Constitutional Electoral Reforms and Politics in Singapore, Legislative Studies Quarterly 27(4) pp. 659-672.

New Straits Times (2013) Malaysia's $13^{\text {th }}$ General Election results. Retrieved from: http://www.nst.com.my/ge13 
Nohlen, D., Grotz, F. and Hartmann, C. (2001) Elections in Asia and the Pacific : A Data Handbook: Volume II: South East Asia, East Asia, and the South Pacific p.152 (London: Oxford University Press).

O'Callaghan, J. (2013, Jan 27) Election loss forces Singapore into delicate balancing act, Reuters. Retrieved from: http://news.yahoo.com/election-loss-forces-singapore-delicatebalancing-act-113205010--business.html

Ortmann, S. (2011) Singapore: Authoritarian but Newly Competitive, Journal of Democracy 22(4) pp. 153-164.

Oswald, K. (2013) How to Win a Lost Election: Malapportionment and Malaysia's 2013 General Election, The Roundtable: The Commonwealth Journal of International Affairs 102(6) pp. 521-532, DOI: 10.1080/00358533.2013.857146

Przeworski, A. and Limongi, F. (1997) Modernization: Theories and Facts, World Politics 49(2) pp. 155-183.

Pandian, S. (2010) Malaysia $12^{\text {th }}$ General Election: An Analysis, European Journal of Social Sciences 14(4) pp. 508-523. Retrieved from:

http://www.eurojournals.com/ejss $14 \quad 4$ 02.pdf'

Quadir, F. and Lele, J. (2005) (eds) Democracy and Civil Society in Asia (London: Palgrave).

Saravanamuttu, J. (2009) Malaysia: Political Transformation and Intrigue in an Election Year, Southeast Asian Affairs Vol. 2009, pp.173-192.

Saravanamuttu, J. (2004) Malaysian Multicultural Policy and Practices: Between Communalism and Consociationalism. In Cheah, B.K., The Challenge of Ethnicity, Building a Nation in Malaysia (ed.) pp.89-114. (Singapore: Marshall Cavendish)

Schedler, A. (2002) The menu of manipulations, Journal of Democracy, 13(2) pp.36-50.

Sin Chew Jit Poh (2008) 2008 Election results. Retrieved from: http://www.sinchewi.com/special/election2008/result.phtml 
Singapore Elections (n.d.a) Legislative Assembly General Election 1963. Retrieved from: http://www.singapore-elections.com/lega-1963-ge/

Singapore Elections (n.d.b) Parliamentary General Election 2006. Retrieved from: http://www.singapore-elections.com/parl-2006-ge/

Singapore Elections (n.d.c) Parliamentary General Election 2011. Retrieved from: http://www.singapore-elections.com/parl-2011-ge/

Singapore Elections (n.d.d) Parliamentary By-Election 2012. Retrieved from:

http://www.singapore-elections.com/parl-2012-be/

Singapore Elections (n.d.e) Parliamentary By-Election 2013. Retrieved from: http://www.singapore-elections.com/parl-2013-be/

Singapore Statistics Department (2013a) Household income and expenditure 2012. Retrieved from:

http://www.singstat.gov.sg/Publications/publications and papers/household income an $\underline{\mathrm{d} \text { expenditure/pp-s19.pdf }}$

Singapore Statistics Department (2013b) Population Trends 2012. Retrieved from: http://www.singstat.gov.sg/pubn/popn/population2012b.pdf

Singh, B. (2006) Politics and Governance in Singapore: An Introduction (Singapore: McGraw-Hill).

Slater, D. (2012) Southeast Asia: Strong State Democratization in Malaysia and Singapore, Journal of Democracy 23(2) pp. 19-33.

Slater, D. and Fenner, S. (2011) State Power and Staying Power: Infrastructural Mechanisms and Authoritarian Durability, Journal of International Affairs 65(1) pp. 15-29.

Subramaniam, S. (2011) Assessing Political Dynamics in Contemporary Malaysia: Implications for Democratic Change, ASIANetwork Exchange 19(1) pp. 42-52

Stewart, I. (2003) The Mahathir Legacy: a Nation Divided, a Region at Risk (London: Allen \& Unwin). 
Tan, E. (2012) Singapore: Transitioning to a "New Normal" in a Post-Lee Kuan Yew Era, Southeast Asian Affairs Vol. 2012, pp.265-282.

Ufen, A. (2008) The 2008 Elections in Malaysia, Uncertainties of Electoral Authoritarianism, Taiwan Journal of Democracy 4(1) pp.155-169. Retrieved from: http://www.tfd.org.tw/docs/dj0401/155-170-Andreas\%20Ufen.pdf

Vasil, R. (2000) Governing Singapore : A history of national development and democracy (Sydney: Allen \& Unwin).

Verweij, M. and Pelizzo, R. (2009) Singapore: Does Authoritarianism Pay? Journal of Democracy 20(2) pp.18-32.

Wain, B. (2009) Malaysian Maverick: Mahathir Mohamad in Turbulent Times (London: Palgrave Macmillan).

Walsh, B. (1996) Atitudes towards democracy in Malaysia, Challenges to the Regime, Asian Survey 35(9) pp. 882-903.

Welsh, B. (2013) Malaysia's Elections: A Step Backward, Journal of Democracy 24(4) pp. 136-150.

Wong, C.H., Chin, J. and Othman, N. (2010) Malaysia - towards a typology of an electoral one-party state, Democratization, 17(5) pp.920-949. 